\title{
Poder normativo das agências reguladoras: as imagens nas embalagens de produtos derivados de tabaco exigidas pela Anvisa*
}

Sérgio Guerra**

A consulente informa que em 6 de agosto de 2008 foi editada a Resolução da Diretoria Colegiada - RDC n 54, que visa alterar a RDC nํ3ㄹ, de 21 de novembro de 2003, e que, por sua vez, dispõe sobre as embalagens de produtos fumígenos derivados do tabaco.

Ademais disso, as novas imagens e frases de advertência das embalagens de produtos derivados de tabaco, objeto da citada RDC nº 54, de 6 de agosto de 2008, da Agência Nacional de Vigilância Sanitária (Anvisa), foram publicadas no Diário Oficial da União do dia 7 de agosto de 2008 e, deste modo, deverão ser usadas de forma simultânea ou rotativa e a indústria não poderá manter a mesma frase e ilustração por mais de cinco meses.

Segundo divulgado pela Anvisa na imprensa, as fotos e mensagens foram produzidas com base em um estudo acerca do grau de aversão que as ilustrações alcançam. Esses estudos teriam sido desenvolvidos no período compreendido entre 2006 e 2008 pelo Inca (Instituto Nacional de Câncer) em parceria com a Anvisa, pelo Laboratório de Neurobiologia da Universidade Federal do Rio de Janeiro (UFRJ), pelo Laboratório de Neurofisiologia do Comportamento da Universidade Federal Fluminense (UFF) e com o Departamento de Artes \& Design da Pontifícia

\footnotetext{
* Parecer publicado com supressão de algumas partes, a exemplo de textos normativos.

** Mestre e doutor em direito. Professor titular de direito administrativo do Curso de Graduação e de direito regulatório do Curso de Mestrado e MBA em Poder Judiciário da Escola de Direito do Rio de Janeiro da Fundação Getulio Vargas (FGV Direito Rio).
} 
Universidade Católica do Rio de Janeiro (PUC-Rio). Foi informado ainda que o estudo teria medido a reação emocional de 212 jovens entre 18 e 24 anos, fumantes e não fumantes, de três faixas de escolaridade (ensinos fundamental, médio e superior), divididos igualmente entre homens e mulheres.

A consulta formulada pela consulente consiste em examinar se a Anvisa, cuja natureza jurídica é de autarquia especial, tem ou não competência para a edição de normas regulatórias nos moldes da RDC no 54, de 6 de agosto de 2008, e quais seriam os limites para essa normatização. Ademais disso, a consulente informa que não foram observados aspectos procedimentais na edição dessa mesma norma que possibilitassem a sua participação e de toda a sociedade, não tendo havido os adequados procedimentos de formação do consenso e tomada de decisão coletiva sobre essa forte intervenção estatal imposta às empresas que compõem a indústria do tabaco e aos cidadãos, fumantes ou não.

Em face do relato, indaga: quais os limites que balizam as escolhas de conveniência e oportunidade da administração pública na condução de suas políticas? As escolhas administrativas da Anvisa, como executora de políticas de controle do tabagismo, teriam os mesmos limites? Tendo em vista que parte das imagens que compõem o rol de advertências gráficas editadas pela Anvisa na Resolução da Diretoria Colegiada n⿳ำ 54, de 2008, espelham informações médicas inverídicas, pergunta-se: tais imagens extrapolariam os limites legais e razoáveis da discricionariedade administrativa daquela autarquia?

As indagações serão respondidas, nos termos que se seguem, após a digressão mínima necessária à pré-compreensão da questão. Ao final serão apresentados os argumentos jurídicos resumidamente.

\section{A regulação estatal de atividades econômicas e o papel das agências reguladoras na busca do equilíbrio de subsistemas, do exercício do poder de polícia, do fomento e da exploração de bens públicos}

Com as premissas da pós-modernidade e que acabaram por impor fortes mudanças na condução da ordem econômica em diversos países, notadamente na Europa durante a década de 1980, o modelo de estado regulador foi confirmado no Brasil com a promulgação da Constituição Federal de 1988. Nesse novo sistema, o modelo liberal e o intervencionismo social cedem lugar à intervenção estatal na ordem econômica social, impondo-se que novas necessidades sejam identificadas e expostas, especialmente para que o Estado neutralize os excessos e se valha de seu dever como instrumento de controle da atuação privada. 
Diante desse contexto e sob o aspecto orgânico, a administração pública direta, considerando a premente necessidade de atrair investimentos - sobretudo estrangeiros -, decidiu abrir mão da função de regular diretamente os subsistemas privatizados de telecomunicações, energia elétrica, transportes etc., conferindo essa função a entidades reguladoras independentes.

Conforme advertência de Sabino Cassese (2006:151), a regulação existe quando a classe política se libera de uma parte de seus poderes a favor de entidades não eleitas pelo povo, que são capazes de bloquear as decisões das eleitas. Para que essa condição ocorra, não basta a separação entre regulador e operador. É preciso, também, a separação entre regulador e governo, cujo fim é evitar a politização das decisões. Ele permite distinguir toda forma de intervenção ou controle desenvolvida sob a direção do governo da regulação em sentido estrito.

O modelo regulatório decorre do fenômeno de "mutação constitucional", desencadeado pelas alterações estruturais por que passou a sociedade e que esse acontecimento teve como consequência, no plano das instituições políticas, o surgimento do imperativo de mudança nas formas de exercício das funções estatais clássicas. O fenômeno da regulação, tal como concebido nos dias atuais, nada mais representa do que uma espécie de corretivo indispensável a dois processos que se entrelaçam. De um lado, trata-se de um corretivo às mazelas e às deformações do regime capitalista e, de outro, um corretivo ao modo de funcionamento do aparelho do Estado engendrado por esse mesmo capitalismo.

Diante desses fatos, quais devem ser os objetivos dessa função regulatória descentralizada, adotada em diversos países, inclusive no Brasil? São várias as razões para a adoção do modelo de regulação estatal por entidades independentes, ao invés da regulação direta pelo Poder Executivo. ${ }^{2}$

Uma dessas razões está atrelada ao novo sentido de regulação administrativa (Moreira e Maças, 2003:10). Com efeito, no modelo intervencionista havia uma confusão entre intervenção direta estatal na atividade econômica e as tarefas regulatórias e, em várias situações, a função regulatória competia ao próprio operador público, muitas vezes sob a figura do monopólio. Com o aparecimento de novos operadores privados na execução de atividades econômicas e serviços públicos, entendeu-se que deveria haver uma separação das funções de regulação e as funções de participação pública na própria atividade regulada. ${ }^{3}$

\footnotetext{
${ }^{1}$ Gomes, Joaquim B. Barbosa. Agências reguladoras: a "metamorfose" do Estado e da democracia (uma reflexão de direito constitucional e comparado). Revista de Direito da Associação dos Procuradores do Novo Estado do Rio de Janeiro (Direito da regulação), v. IX. Alexandre Santos de Aragão (Org.). Rio de Janeiro: Lumen Juris, 2002, p. 90.

${ }^{2}$ Para um aprofundamento das razões, ver Guerra (2008), notadamente o capítulo I.

${ }^{3}$ Conrado Hübner Mendes (2000:108) aduz: "As empresas que saem do domínio estatal e passam a fazer parte do domínio privado não podem estar submetidas, exclusivamente, às livres decisões de
} 
Um processo de regulação implica, tipicamente, várias fases, em que se destacam a formulação das orientações da regulação, a definição e operacionalização das regras, a implementação e aplicação das regras, o controle da aplicação das regras, o sancionamento dos transgressores e a decisão nos recursos (Souto, 2001:441).

Entretanto, o principal objetivo perseguido com a instituição de um modelo estatal regulatório é a cessão de capacidade decisória sobre aspectos técnicos para entidades descentralizadas em troca de credibilidade e estabilidade, demonstrando-se, com isso, que a regulação estatal precisa ser despolitizada, precisa ser razoável e proporcional, deve deixar de ser assunto de governo para ser assunto de Estado.

Adveio, com a globalização, a obrigação de se gerar salvaguardas institucionais que signifiquem um compromisso do Estado brasileiro com a manutenção de regras, autorizações, contratos, privilegiando assim a segurança jurídica e o equilíbrio de subsistemas regulados. ${ }^{4}$

Por esse novo papel do Estado regulador se busca o abandono do perfil autoritário, da edição de normas em gabinetes herméticos e que excluam a participação da sociedade, tudo em prol de maior interlocução do Poder Público com o cidadão, com empresas privadas, entidades de classes etc. Enquanto na perspectiva do liberalismo compete ao Poder Público assegurar as regras do jogo para livre afirmação das relações de mercado e, no modelo social, inverte-se esse papel, de modo que a atividade estatal seja a provedora das necessidades coletivas, ao Estado regulador são exigidas funções de equalização, mediação e arbitragem das relações econômicas e sociais, ponderados os interesses em presença (Marques Neto, 2002:13-29).

Nessa ordem de convicções, a concepção regulatória retrata uma redução nas diversas dimensões da intervenção estatal no âmbito econômico, incorporando uma concepção de subsidiariedade (Justen Filho, 2002:21). Isso importa reconhecer os princípios gerais da livre-iniciativa, reservando-se ao Estado o instrumento da regulação como meio de orientar razoavelmente e proporcionalmente a atuação dos particulares à realização de valores fundamentais. A importância da função regulatória está em conformar a garantia de equilíbrio de um subsistema, por meio de mecanismos para sua efetividade com vistas ao ajuste das oscilações econômicas, mesmo contra suas próprias regras.

A atividade administrativa, mais do que instrumento de definição autoritária do direito aplicável, vai, aos poucos, tornando-se um mecanismo de composição e

seus administradores, motivadas unicamente pelas contingências econômicas. Devem, sim, estar em consonância com interesses que transcendem os meramente capitalistas. Por esse motivo, ao retirar da máquina estatal tais empresas, nasce a necessidade de regulá-las intensamente".

${ }^{4}$ Subsistema regulado é aquele apontado por Floriano de Azevedo Marques Neto (2000:301), como sendo parcelas do ordenamento jurídico pautadas por princípios, conceitos e estruturas hierárquicas próprios a determinado setor. 
ponderação de interesses públicos e privados, que se manifestam no procedimento, e que os órgãos de decisão devem regular de maneira a tomar a decisão mais adequada, necessária e proporcional, e que melhor salvaguarde os direitos subjetivos e os interesses em presença.

Essa forma de intervenção estatal (regulação) deve atender ao interesse público, sem, contudo, deixar de sopesar os efeitos e impactos dessas decisões no subsistema regulado com os interesses de segmentos específicos da sociedade e, até mesmo, com o interesse individual no caso concreto (com a dignidade da pessoa humana).

Nesse campo de questões, as atribuições estatais, no contemporâneo Estado regulador - confirmado, entre nós, com a promulgação da Carta de 1988 -, deve atentar para a justiça material no caso real, impossível de ser previsível e positivada, na maioria das vezes, pelo poder legiferante, como adiante será abordado.

É sabido que nas principais questões submetidas à regulação estatal sistêmica, as normas têm linhas mestras da política econômica e social, fazendo com que exista uma liberdade ao administrador público na hora de executar os comandos gerais da norma, dependendo:

dos dados empíricos decorrentes das técnicas disponíveis e testadas;

$>$ da circunstância fática em que a norma está sendo aplicada;

$>$ dos impactos prospectivos multilaterais decorrentes do ato.

Assim, faz parte do objetivo do Estado regulador a materialização de uma forma de compatibilização dos instrumentos de regulação dentro das premissas decorrentes do Estado democrático de direito, com os riscos que devem ser previstos ou minimizados pela administração pública regulatória: "All over the world, nations are attempting to reduce risks, to improve safety, and to extend lives. Indeed, risk reduction has become a principal goal of modern governments" (Sunstein, 2002:xiii).

Isso porque há um confronto direto entre, de um lado, a necessidade de se estabelecer e respeitar autorizações concedidas legalmente - como no exemplo da atividade econômica desenvolvida pela consulente - e, de outro, a "regulação" dos riscos a que se submete a sociedade e que afetam direitos e garantias fundamentais, como, no caso, a proteção à saúde.

O Estado, para tal, deve intervir adequadamente nessas atividades privadas sensíveis - a vigilância sanitária - em um ambiente de permanente mutação das questões técnicas, situações imponderáveis e das variações socioeconômicas no país.

Para efeitos deste parecer importa perquirir se a regulação exercida pela Anvisa se engasta nesse novo ambiente regulatório, disciplinando por meio de leisquadro (standards), idealizado para buscar o equilíbrio sistêmico de setores estratégicos 
para a sociedade ou se, na verdade, traduz o exercício do poder de polícia clássico submetido ao princípio - também clássico - da legalidade estrita. Para tanto, cumpre examinar como está disciplinada, legalmente, a atividade econômica da indústria do tabaco em uma das modalidades de intervenção estatal, indicadas supra, sobre as atividades econômicas.

\section{A atividade econômica da indústria do tabaco. Princípio da livre-iniciativa. Características}

Impende assinalar que a produção e a comercialização de cigarros, em todo o território nacional, é uma atividade lícita e, nesse sentido, o objetivo social da consulente é fornecer produtos a adultos que escolheram fumar, em princípio, cientes dos riscos associados ao hábito.

Sabe-se que o Brasil é um dos países mais regulados do mundo no que se refere à produção e comercialização dos produtos derivados do tabaco, como se pode constatar na lista de normas que incidem sobre essa atividade econômica privada.

O Estado brasileiro - e a própria indústria do tabaco - , de um lado, reconhece que o produto dessa atividade econômica envolve riscos à saúde e, nesse contexto, se vê diante de uma forte e necessária intervenção das autoridades públicas; contudo, e por outro lado, é um setor altamente tributado pelo Estado. Essa escolha entre conciliar os riscos de saúde e a cobrança de vultosa quantia por meio de impostos, como se vê, foi, desde remota data - e ainda é - a opção política adotada legalmente pelo Poder Público brasileiro para a autorização dessa atividade privada.

Trata-se de uma escolha política discricionária de se disciplinar, por meio de lei, as formas de autorização estatal para produção e comercialização de produtos derivados do tabaco, mesmo diante de riscos à saúde da população e, paralelamente, cobrar dessa atividade econômica alta soma por meio de tributos. A regulação estatal sobre essas atividades econômicas, como qualquer outra atividade lícita, deve ser nos limites constitucionais, legais e, mais do que isso, que atendam ao bloco de juridicidade que norteia a conduta das autoridades públicas em um Estado democrático de direito.

A natureza da atividade aqui comentada é, à luz da normativa indicada supra, inquestionavelmente lícita, havendo divulgação, por meio de vários mecanismos criados pelo Estado e com fulcro maior na Carta de 1988, dos riscos associados ao consumo de cigarros, envolvendo, em parte, a livre escolha dos consumidores. Esse aspecto, ademais, independentemente de ser favorável ou não ao tabagismo, tem sido reconhecido por representantes do Poder Judiciário brasileiro. 
Conclusivamente, identificam-se, assim, duas formas de intervenção estatal, entre as indicadas neste parecer, sobre a indústria do tabaco. Primeiramente, há o disciplinamento legal da atividade, com inúmeras restrições para autorização desta diante dos riscos à saúde e, posteriormente, a atividade passou, desde 1999, a sofrer regulação estatal descentralizada por meio da Agência Nacional de Vigilância Sanitária (Anvisa), autarquia de regime especial.

Diante desse quadro, passa-se a examinar a concepção de regulação de vigilância sanitária.

\section{O Sistema Único de Saúde - SUS. A concepção de regulação de vigilância sanitária. A ausência de regulação sistêmica no que se refere à indústria do tabaco. A competência outorgada para o exercício descentralizado e reforçado do poder de polícia estatal}

Considerando que a atividade econômica da indústria do tabaco é, além de disciplinada por lei, fiscalizada por uma entidade reguladora descentralizada do poder público central, é de aguda importância, para compreensão dos limites de sua atuação, a análise do nível de "concepção de regulação" exercido pela Anvisa. Isso porque a terminologia "regulação da atividade econômica" apresenta mais de um sentido jurídico, dependendo do contexto em que for utilizada.

Com efeito, o termo pode ser interpretado tanto como significando um conjunto de atividades estatais voltadas à "regulamentação" de um determinado setor específico da economia (como, por exemplo, os setores de telecomunicações, energia, seguros de saúde, petróleo, entre outros), mas também como o conjunto das atividades estatais voltadas à fiscalização e "regulamentação" sobre a generalidade dos agentes da economia, como é o caso das atividades exercidas pelos órgãos ambientais e de defesa da concorrência. ${ }^{5}$

Espelhando a pluralidade de significados que o termo pode abarcar, observa Vital Moreira:

Quanto à amplitude do conceito, aparecem-nos três concepções de regulação:

\footnotetext{
${ }^{5}$ Sundfeld, Carlos Ari. Introdução às agências reguladoras. In: Sundfeld, Carlos Ari (Coord.). Direito administrativo econômico. São Paulo: Malheiros, 2000, p. 18. Explica ainda o autor: "A regulação, enquanto espécie de intervenção estatal, manifesta-se tanto por poderes e ações com objetivos claramente econômicos (o controle de concentrações empresariais, a repressão de infrações à ordem econômica, o controle de preços e tarifas, a admissão de novos agentes no mercado) como por outros de justificativas diversas, mas de efeitos econômicos inevitáveis (medidas ambientais, urbanísticas, de normalização, de disciplina das profissões etc.)".
} 
(a) em sentido amplo, é toda forma de intervenção do Estado na economia, independentemente de seus instrumentos e fins;

(b) num sentido menos abrangente, é a intervenção estatal na economia por outras formas que não a participação direta na atividade econômica, equivalendo, portanto, ao condicionamento, coordenação e disciplina da atividade econômica privada;

(c) num sentido restrito, é somente o condicionamento normativo da atividade econômica privada (por via de lei ou outro instrumento normativo). ${ }^{6}$

Nesse contexto, indaga-se: por quais razões a vigilância sanitária passou a ser descentralizada do poder público central, em especial, materializando-se por meio de uma autarquia de regime especial, a Anvisa, a exemplo do que havia ocorrido com os setores de telecomunicações, energia elétrica, petróleo e gás etc.?

Cumpre, para essa análise, examinar os antecedentes sobre o tema.

É assinalável que em 1976, pelo Decreto n⿳0 79.056, foi criada a Secretaria Nacional de Vigilância Sanitária (SNVS), com o objetivo de proteger a saúde do consumidor, através de ações no controle da qualidade dos produtos de interesse da saúde: alimentos, cosméticos, domissanitários e medicamentos.

Para dar suporte às ações da Vigilância Sanitária foram editados alguns textos normativos, referentes ao comércio de drogas, entre eles a Lei no 5.991/73, regulamentada pelo Decreto $\mathrm{n}^{\mathrm{o}} 54.170 / 74$, que dispõe sobre o controle sanitário do comércio de drogas, medicamentos, insumos farmacêuticos e correlatos; a Lei n⿳ 6.360/76, regulamentada pelo Decreto $\mathrm{n}^{\mathbf{0}} 74.170 / 77$, que dispõe sobre a produção de medicamentos; e a Lei no 6.437, de 20 de agosto de 1977, que configura infrações à legislação sanitária federal e estabelece as sanções respectivas.

A Secretaria Nacional de Vigilância Sanitária (SNVS), com uma deficiência estrutural, em que faltavam recursos humanos e administrativos, normas para operacionalização e laboratório, não supria a demanda das empresas fabricantes dos produtos regulados, tornando-se um cartório ineficiente.

O desenvolvimento industrial acelerado exigiu maior agilidade da SNVS. Essas práticas resultaram na liberação para o comércio de alguns produtos sem critérios técnicos e científicos, e registros eram aprovados sem maiores estudos e análises.

Com a promulgação da Constituição de 1988, a Vigilância Sanitária ganhou importância dentro do capítulo da saúde, que foi reforçado pela Lei Orgânica da Saúde no 8.080/90 (lei que disciplina os preceitos constitucionais do SUS - Sistema Único de Saúde) ao se integrar ao conjunto das competências do SUS.

\footnotetext{
${ }^{6}$ Moreira, Vital. Auto-regulação profissional e administração pública. Coimbra: Almedina, 1997, p. 35. Comumente, a doutrina administrativista utiliza a terminologia em seu segundo significado.
} 
Entre os avanços sociais perpetrados pela Carta de 1988, a necessidade da criação de um sistema amplo de tutela da saúde pública não passou despercebida pelo legislador constituinte originário.

A Carta política reservou, em especial, a Seção II, do Capítulo II, do Título VIII, que trata da Ordem Social, para fixar os comandos normativos a serem observados nas disposições relativas à saúde, definida no caput do art. 196 como "direito de todos e dever do Estado".

A especial atenção dada pelo legislador constituinte à saúde pública também se reflete na competência outorgada a todos os entes da federação para legislarem sobre essa matéria, ex vi do inciso XII, do art. 24 e incisos I e II, do art. 30, ambos da Constituição da República.

Com efeito, além de definir a saúde como um direito assegurado a todos, o legislador constituinte foi adiante e, a fim de dar efetividade às suas disposições, estabeleceu as diretrizes básicas do sistema de tutela desse direito fundamental, dizendo nos arts. 197 e 198 da Constituição da República, in verbis:

Art. 197. São de relevância pública as ações e serviços de saúde, cabendo ao Poder Público dispor, nos termos da lei, sobre sua regulamentação, fiscalização e controle, devendo a execução ser feita diretamente ou através de terceiros e, também por pessoa física ou jurídica de direito privado.

Art. 198. As ações e serviços públicos de saúde integram uma rede regionalizada e hierarquizada e constituem um sistema único, organizado de acordo com as seguintes diretrizes:

I - descentralização, com direção única e em cada esfera de governo; [...].

Ao sistema único de saúde, regionalizado e descentralizado na forma instituída pelo art. 198, o legislador constituinte originário atribui competências específicas, conforme dispõe o art. 200 da Constituição da República, in verbis:

Art. 200. Ao sistema único de saúde compete, além de outras atribuições, nos termos da lei:

I - controlar e fiscalizar procedimentos, produtos e substâncias de interesse para a saúde e participar da produção de medicamentos, equipamentos, imunobiológicos, hemoderivados e outros insumos;

II - executar as ações de vigilância sanitária e epidemiológica, bem como as de saúde do trabalhador; [...]. 
Cumprindo a imposição constitucional de criação de um sistema único de saúde, regionalizado e descentralizado em cada esfera de governo, conforme dicção expressa da Constituição da República, e diante das competências a ele atribuídas, o legislador ordinário editou a Lei no 8.080, de 19 de setembro de 1990, que dispôs sobre a participação da União, dos Estados, Distrito Federal e Municípios na composição do sistema único de saúde, cada um exercendo suas atribuições específicas, conforme determina a repartição constitucional de competências.

Dispõe a Lei $\mathrm{n}^{\mathrm{o}}$ 8.080/90, in verbis:

Art. 15. A União, os Estados, o Distrito Federal e os Municípios exercerão, em seu âmbito administrativo, as seguintes atribuições:

XX - definir as instâncias e mecanismos de controle e fiscalização inerentes ao poder de polícia sanitária;

Art. 16. À direção nacional do Sistema Único de Saúde (SUS) compete:

$[\ldots]$

III - definir e coordenar os sistemas:

$[\ldots]$

d) vigilância sanitária;

$[\ldots]$

VII - estabelecer normas e executar a vigilância sanitária de portos, aeroportos e fronteiras, podendo a execução ser complementada pelos Estados, Distrito Federal e Municípios;

VIII - estabelecer critérios parâmetros e métodos para o controle da qualidade sanitária de produtos, substâncias e serviços de consumo humano; [...].

De fato, para o exercício das competências específicas, fixadas pela Carta Magna e disciplinadas na legislação inferior, coube a cada ente da Federação adequar sua estrutura de saúde às imposições do SUS, especialmente quanto ao poder de polícia de vigilância sanitária, tendo em vista sua peculiar natureza, que comporta ações que vão desde a proteção da saúde local no menor e mais longínquo dos municípios brasileiros, até aquelas que demandam atuação em âmbito nacional.

Nesse sentido, abordando a repartição do poder de polícia administrativa entre os entes federativos, em que se insere a vigilância sanitária, colhe-se a cátedra de Celso Antônio Bandeira de Mello (2002:719), in verbis:

As três entidades jurídicas de capacidade política, União Estados e Municípios desempenham atividades de polícia administrativa. O problema que se 
coloca é o de saber-se quais os campos em que incidirá a atuação de cada uma delas. Como critério fundamental, procede dizer-se que é competente para dada medida de polícia administrativa quem for competente para legislar sobre a matéria. Assim, a União exercerá em caráter exclusivo polícia administrativa sobre o que estiver arrolado no art. 22 da Constituição e concorrentemente com os Estados e Distrito Federal sobre o que consta no art. 24. Estados irão exercitá-la em caráter exclusivo nas hipóteses abrigáveis no $\S 1^{\mathrm{o}}$ do art. 25 ou em concorrência com a União nas do art. 24, precitado. Municípios têm seu campo exclusivo de polícia administrativa no que disser respeito ao seu peculiar interesse, notadamente as matérias previstas no art. 30. O Distrito Federal, a quem compete, por força do art. $32, \S 1^{\circ}$, atribuições correspondentes a dos Municípios e as dos Estados (salvo no que concerne ao $\S 1^{\mathrm{o}}$ do art. 25 ), exercerá polícia administrativa em caráter exclusivo no mesmo caso em que os Municípios a exercem e concorrentemente nas hipóteses do art. 24. Sucede que a recepção do critério lembrado exige certas precisões para prevenir equívocos. Com efeito, muitas matérias há relacionadas com a competência da União que, quando ao fundo, só a elas são pertinentes, mas que repercutem diretamente sobre interesses peculiares do Município e por isso mesmo são suscetíveis de serem por ele reguladas e asseguradas nos aspectos que interferem com a vida e a problemática municipais. Eis porque este exercerá sua atividade de polícia na salvaguarda dos interesses pertinentes ao seu âmbito de ação mesmo quando, à primeira vista, em exame menos arguto, pudesse fazer parecer tratar-se de problema afeto a Estados ou União, nos termos da discriminação constitucional.

Como se vê, a vigilância sanitária sobre a indústria do tabaco é um exemplo típico dessa hipótese, que se insere no clássico poder de polícia estatal ora reforçado com a estrutura materializada sob a forma de autarquia de regime especial.

Sem dúvida, a competência para legislar sobre saúde pública e, portanto, sobre vigilância sanitária está na esfera de todos os entes federativos: para a União e os Estados, em razão da competência concorrente prevista no art. 24, XII; e para os Municípios, em razão da competência residual do art. 30, I, ambos da Constituição da República. Contudo, notadamente no que se refere ao plano federal, na década de 1990 foi lançado pelo governo Collor o projeto Inovar, com o objetivo de agilizar o processo de registros dos medicamentos. O projeto, entretanto, acabou gerando análises técnico-científicas apressadas e deficientes. Apesar da espantosa quantidade de produtos colocados no mercado, esse momento caracterizou-se por uma crescente participação da sociedade civil e pela visão da vigilância sanitária como ação da cidadania focada na questão do risco.

Nesse contexto, em 1999, em substituição à Secretaria Nacional, foi criada a Agência Nacional de Vigilância (Anvisa), através da Lei no 9.787/2000, com algu- 
mas peculiaridades, como, por exemplo, ter autonomia orçamentária, através da arrecadação de taxas dos serviços prestados, pessoal e estrutura própria, como estabilidade administrativa dos seus dirigentes (mandatos fixos).

A principal justificativa utilizada para a criação da Anvisa se baseava no questionamento da estrutura existente, que se mostrava inoperante para exercer o controle da eficácia e segurança dos produtos e dos fabricantes, considerando os episódios sucessivos de falsificações de produtos controlados vivenciados em 1998.

Desse modo, pode-se concluir neste tópico que a estruturação do controle e da fiscalização da vigilância sanitária no Brasil decorreu de razões diversas de outros setores (ou melhor, subsistemas) que passaram a ser regulados por agências reguladoras, a exemplo dos sistemas desestatizados de telecomunicações, distribuição de energia elétrica e transportes públicos.

É possível concluir que a Anvisa não se enquadra na modelagem regulatória descentralizada, como ocorreu na estruturação dos setores que envolvem a regulação de serviços públicos desestatizados (Aneel, Anatel, ANTT, Antaq, Anac), nem, tampouco, na regulação de atividade monopolizada (ANP), na exploração de bens públicos (ANA), no fomento (Ancine) ou mesmo na regulação de atividade econômica em área sensível à sociedade e com risco microssistêmico (ANS). A Anvisa se apresenta como uma regulação de atividade econômica não sistêmica (no caso da indústria do tabaco), voltada ao controle e fiscalização nos moldes clássicos do poder de polícia estatal.

Partindo-se dessa premissa, resta perquirir se as normas expedidas pela Anvisa (resoluções), a exemplo da RDC no 54/2008, objeto deste parecer, se enquadra - ou não - na doutrina atual que sustenta existir certa transformação (mutação) no direito administrativo (pós-moderno) que atrai teoria doutrinária cunhada no início do século passado na Itália, e difundida em vários países, denominada de "discricionariedade técnica" ou, até mesmo, se configura discricionariedade administrativa clássica quando se está diante da escolha regulatória feita por entidade estatal descentralizada.

\section{A constitucionalidade da normatização regulatória secundária por entidades reguladoras independentes. O não enquadramento na teoria da discricionariedade administrativa ou técnica. A necessária maleabilidade das normas econômicas para equilíbrio sistêmico. As peculiaridades da regulação normativa exercida pela Anvisa}

Com o amplo processo neoliberalizante empreendido no Brasil, buscou-se uma mudança do papel do Poder Executivo na regulação de atividades econômicas. 
Nesse cenário, para compor a relação entre os interesses públicos e privados, o Estado intervém sob várias formas, como dito supra. Essencialmente, para o exercício desse "poder-dever" sob a forma regulatória, o Estado se vale de normas jurídicas, com vistas a conduzir as políticas econômicas e sociais ao equilíbrio entre os interesses pluralistas envolvidos e que, em grande parte, se encontram em situação contraposta.

Se, de um lado, o poder de decisão das questões de natureza política primária compete ao Poder Legislativo na edição de normas jurídicas, por outro parece ser indisputável que a lei tem dificuldade para disciplinar o direito nos detalhes que a solução dos problemas cotidianos submetidos à regulação sistêmica exige.

Há necessidade de que o Poder Executivo (e, no atual formato, as agências reguladoras) tenha, em muitas situações, de atuar sem uma conduta totalmente predeterminada por uma regra legal, sempre, porém, balizado por certos limites jurídicos.

Nesse contexto, a doutrina publicista, desde remota data, trilha o caminho do poder regulamentar para a consecução de tal desiderato, fundamentando, nessa linha de pensamento, a impossibilidade da simples aplicação mecânica da lei pelo administrador público sem qualquer inovação.

Por sua vez, além de os regulamentos destinarem-se a dar fiel execução à lei e, nesse caso, estarem a ela vinculados, sustenta-se, doutrinariamente, a existência de regulamentos autônomos, supostamente expedidos dentro da competência discricionária conferida por lei à administração. Para alguns autores, há excesso de rigorismo na doutrina publicista pátria que advoga o purismo nessa matéria, no sentido de não admitir a teoria dos regulamentos autônomos em nosso ordenamento jurídico, mas sim, e apenas, a do regulamento por decreto executivo, dito regulamentar, que se presta a detalhar a lei quanto a seu modo de execução, e que deve orientar-se secundum legem, jamais praeter legem.

Esse é o ponto nevrálgico da questão que envolve a função normativa das agências reguladoras.

Tanto os que querem defender a função normativa das entidades reguladoras independentes quanto aqueles que são contra essa função conduzem, em regra, o debate sobre o tema para esse campo de questões.

Cabe ressaltar, de início, que a polêmica doutrinária suscitada acerca da função normativa das entidades reguladoras deve-se, em parte, ao fato de que a Constituição Federal, em seu art. 25 do Ato das Disposições Constitucionais Transitórias, revogou todos os dispositivos legais que atribuem ou deleguem a órgão do Poder Executivo competência assinalada ao Congresso Nacional.

Some-se a isso o fato de que a Constituição Federal de 1988, por meio de emendas, faz menção à criação de apenas dois agentes reguladores, sendo o primeiro referente ao controle e à fiscalização das concessões ou permissões dos serviços 
de telecomunicações, e o segundo refere-se às atividades econômicas voltadas à indústria do petróleo.

Por outro lado, os argumentos utilizados a favor da admissão do exercício dessa função por essas entidades são: a crise do princípio da legalidade e o surgimento de outras formas de produção normativa, a distinção entre relações jurídicas gerais e relações jurídicas especiais, a complexidade dos temas econômicos, e a necessidade de flexibilização e rápida adaptação das normas.

Parece, ao signatário, ${ }^{7}$ não haver dúvidas quanto à juridicidade de as entidades reguladoras exercerem uma função normativa, desde que observadas normas hierarquicamente superiores, a exemplo de diversas outras autarquias, especiais ou não. Essas normas, expedidas pelas agências, não são primárias. São secundárias.

A função normativa primária é precípua do Poder Legislativo, sendo exercida de forma extravagante pelo Poder Executivo, seja por meio de medidas provisórias ou delegação legislativa - casos em que não se enquadra a função normativa das entidades reguladoras independentes. Isto é, ela deve se traduzir no fiel detalhamento das condições de realização de direitos, deveres e demais disposições normativas previstas, explícita ou implicitamente, na lei que lhe confere fundamento de validade.

O argumento presente é de que há certas hipóteses em que não é possível conferir fiel regulamentação à lei sem dispor sobre certos aspectos implícitos na ratio essendi daquela, e sem cuja normatização, por inteiro, e em todos seus aspectos, sobretudo os de ordem técnica, não é possível conferir-lhe fiel executoriedade.

Para o signatário, esse debate conduz o tema para o sítio da discricionariedade. Isto é, o debate travado em sede doutrinária não anula o efeito de conduzir a função normativa das agências reguladoras pela via da discricionariedade administrativa.

Desse modo, é jurídico concluir que tanto faz, portanto, falar-se, no caso das normas regulatórias, quer em regulamento delegado, quer em regulamento executivo ou autônomo incidente sobre o sítio da discricionariedade. Em essência, é tudo o mesmo, pois se operam dentro dos padrões legais e, portanto, intra legem.

Acerca do tema, vale colacionar os comentários de Clèmerson Merlin Clève $(2000: 307):^{9}$

Nesse campo, a Administração atua em virtude de delegação (autorização) do Legislativo, podem afirmar alguns. Aí, não há delegação, porque a Administração simplesmente executa a lei, podem afirmar outros. Ora, admitase que a diferença entre as posições é meramente nominal. Designados como regu-

\footnotetext{
${ }^{7}$ Conforme nosso artigo: Guerra (2005b:5).

${ }^{8}$ Cf. Guerra (2008:177-ss).

${ }^{9} \mathrm{O}$ itálico é nosso.
} 
lamentos delegados ou como regulamentos de execução, os rótulos indicam realidade fenomênica única. Idênticos fenômenos, embora com nomes distintos. Ambos constituem regulamento intra legem, aceitos não apenas pela doutrina, como também pela jurisprudência. Com efeito, o Supremo Tribunal Federal, em acórdão prolatado ainda sob a égide da Constituição de 1946, mais perfeitamente compatível com a ordem constitucional em vigor, decidiu que o princípio da indelegabilidade não exclui certas medidas a serem adotadas pelo órgão executor no tocante a fatos e operações de natureza técnica, dos quais dependerá a aplicação da lei.

Como se vê, tanto a delegação legislativa quanto a teoria dos regulamentos (autônomos ou não) não trazem respostas seguras para o enfrentamento da regulação normativa por meio das entidades reguladoras, por não se enquadrarem na modalidade tradicional de regulamentação secundária, conduzindo para a teoria da discricionariedade administrativa.

Diogo de Figueiredo Moreira Neto esclarece a questão ao anotar em artigo específico sobre a função normativa da Anvisa que além da modalidade tradicional da regulamentação secundária, que produz efeitos incontroversos, como característica dos órgãos administrativos, existem aquelas tipicamente regulatórias, que se caracterizam por seus efeitos extroversos sobre as matérias "deslegalizadas" e na estrita medida em que tenham sido. ${ }^{10}$

Esse mesmo jurista, ao examinar os limites da competência normativa outorgada às entidades reguladoras autônomas de serviços públicos, adverte que ultrapassar tais limites, ao acrescentar às normas reguladoras critérios político-administrativos em que não deveriam existir, caracteriza invasão de poderes que são próprios à esfera das decisões do Poder Legislativo e propositadamente retirados dos agentes da burocracia administrativa direta (Moreira Neto, 2003:108-109).

De fato, as entidades reguladoras não recebem competências do Legislativo para formular normas abertas conformadas por aspectos políticos discricionários; por isso, e considerando ser "extremamente difícil submetê-las a uma ordem hierárquica definida" (Moreira Neto, 2006:40), devem merecer um novo enquadramento na clássica pirâmide normativa prevista no vigente texto constitucional brasileiro.

É indene de dúvidas que, no ordenamento jurídico brasileiro, a Constituição Federal está no grau mais elevado da hierarquia, a qual todas as demais normas devem-se adaptar. Em ordem decrescente, têm-se as leis complementares, as leis

\footnotetext{
${ }^{10}$ Moreira Neto, Diogo de Figueiredo. Agência nacional de vigilância sanitária: natureza jurídica, competência normativa, limites dos poderes regulatórios. Revista de Direito Administrativo, v. 215. Rio de Janeiro, p. 71-83, jan./mar. 1999.
} 
ordinárias, os decretos e os demais regulamentos e atos normativos inferiores. Nestes incluem-se as instruções, portarias e resoluções, que, em virtude do princípio da legalidade, têm caráter estritamente subordinado e dependente de lei.

Contudo, em nosso sistema constitucional, essencialmente um sistema normativo de valores - ora contrapostos, ora afinados, mas que se pretendem sempre harmônicos - marcado pela hegemonia axiológica dos princípios, "nenhuma norma de direito positivo se encontra isolada em si, mas sempre inserida dentro de um contexto formado pela ordem jurídica no seu conjunto" (Müller, 1996:275). Desse modo, "perante um problema a resolver, não se aplica, apenas, a norma primacialmente vocacionada para a solução: todo o direito é chamado a depor". ${ }^{11}$

Daí que a missão das entidades reguladoras, como pré-intérpretes da Constituição mediante trabalho exegético que procure encontrar, na autorreferência do subsistema, uma solução de concordância prática entre as normas constitucionais em tese aplicáveis a um determinado caso concreto submetido à regulação é a de fugir dos reducionismos do pensamento catalogador da hierarquia normativa e simplificado sob a forma piramidal, ${ }^{12}$ tudo isso com o intuito de aguçar e intensificar - como dito, à luz das especificidades do caso concreto - o questionamento normativo em sua pluralidade, estabelecendo conexões de valor entre as normas.

Com isso, conclui-se que editar atos normativos regulatórios não se conforma às teorias sobre regulamentos administrativos nem, tampouco, ao instituto da discricionariedade administrativa.

Não se quer dizer que não há espaço para a escolha discricionária em todas as questões que envolvem a regulação estatal descentralizada. É certo que em determinadas situações o regulador deverá atuar discricionariamente, porque a este compete o papel de decidir quando estiver diante de situações que comportam mais de um caminho razoável e proporcional - "meio" - para atingir-se o resultado esperado e voltado para o equilíbrio sistêmico - "fim". Esses atos representam a materialização de escolhas que busquem confrontar o problema a ser solucionado, em face do marco regulatório, e os bens e valores jurídicos que ali estariam conflitando, estabelecendo-se qual ou quais desses valores em conflito deverá prevalecer.

Considerando a proliferação dessas entidades com funções executivas, normativas e judicantes, e tendo em vista que estas foram idealizadas para exercer

\footnotetext{
${ }^{11}$ Ver introdução de António Menezes Cordeiro à edição portuguesa da obra de Claus-Wilhelm Canaris intitulada Pensamento sistemático e conceito de sistema na ciência do direito. Lisboa: Fundação Calouste Gulbenkian, 1996, p. CXI.

12 “O marco regulatório dos serviços públicos é constituído de elementos que não se relacionam apenas de maneira piramidal, havendo uma teia normativa disposta de forma flexível e inter-relacionável, que produz fluxos normativos multidirecionais, tanto de forma horizontal (normas de idêntica hierarquia), como vertical (normas de hierarquia diversa integrantes do mesmo setor normativo) e diagonalmente (normas de hierarquia diversa integrante de distintos setores normativos - ex.: resolução da Anatel versus lei consumerista)" (Aragão, 2007:370).
} 
uma competência técnico-científica, fortemente atrelada à integração paulatina de conceitos jurídicos indeterminados, distantes de critérios e paixões político-partidárias, essas características conformariam, segundo alguns, ${ }^{13}$ uma discricionariedade supostamente diferenciada.

Também não nos parece poder vingar a tese de que se trata de uma discricionariedade técnica.

Como preconizamos em sede doutrinária (Guerra, 2005a:207):

O termo discricionariedade técnica visa apenas uma limitação jurisdicional do controle do seu exercício, no sentido de evitar que as escolhas técnicas da Administração não sejam substituídas pelas opções técnicas realizadas pelo juiz. Não se identifica no ordenamento nenhum instituto juridicamente aplicável à discricionariedade técnica como uma pseudoespécie da discricionariedade administrativa.

Na lição de Meilán Gil (2006:126), a função normativa do Estado pode se dirigir tanto à regulação dos meios e requisitos técnicos para a prestação do serviço, de acordo com as inovações que se produzem, como redefinindo o conteúdo das obrigações. E afirma: "una adecuada apreciación de la realidad social obligará a ponderar la amplitud de esa potestad normativa".

Desse modo, não parece haver dúvidas de que as normas editadas por entidades reguladoras devem obedecer aos preceitos legais - standards (Cabral de Moncada, 2002:23) - , pois a administração pública não tem um poder normativo incondicional e geral, como ocorre com o Poder Legislativo. Entretanto, não se pode enquadrar essas normas como uma função regulamentar da lei, de competência do presidente da República, pois, em termos de regulação de atividades econômicas, a lei não consegue prever tudo (portanto, não há discricionariedade que, como se sabe, decorre da abertura legiferante).

A polêmica acerca da função normativa das entidades reguladoras se insere em uma discussão mais profunda, que envolve sua adaptação ao sistema tripartite oitocentista, subsumido no princípio da separação e do equilíbrio entre os poderes estatais, que impõe também uma revisão da hierarquia normativa e do instituto da discricionariedade administrativa. ${ }^{14}$

Nessa ordem de convicções, tivemos a oportunidade de sustentar doutrinariamente (Guerra, 2005a:101) a constitucionalidade do exercício da função normativa

\footnotetext{
${ }^{13}$ Ampla pesquisa sobre o tema pode ser conferida em Guerra (2005a).

${ }^{14}$ Teorizamos, a esse respeito, a criação do instituto da reflexividade: "A reflexividade caminha no sentido de viabilizar a autonomia regulada dos sistemas, permitindo a maximização de sua racionalidade interna mediante adequados procedimentos de formação do consenso e tomada de decisão coletiva" (Guerra, 2008).
} 
secundária pelas entidades reguladoras por não se detectar, em tese, qualquer usurpação da função legiferante, de competência do Poder Legislativo, nem, tampouco, do poder regulamentar de atribuição precípua do chefe do Poder Executivo. ${ }^{15}$

Regulação é mais do que simplesmente baixar atos normativos. Pela regulação se permite o exercício da capacidade técnica das entidades descentralizadas para dispor com maior densidade sobre as matérias que lhe competem para equilibrar o subsistema regulado, diversamente das leis que, editadas pelo Poder Legislativo com certa maleabilidade, assumem caráter genérico e sem concretude.

Resta afirmar, "regular um subsistema" abrange outros institutos muito mais densos do que a "regulamentação" de uma lei, seja de execução ou autônoma.

A função regulatória (ou reguladora) visa a realizar o gerenciamento dos múltiplos e antinômicos interesses da sociedade plural, traduzindo-se "em restrições à autonomia privada para evitar que o exercício abusivo de certas prerrogativas ponha em risco a realização de outros valores" (Justen Filho, 2002:556).

A regulamentação é cometida a chefes de Estado ou Governo, é uma função política, que visa impor regras de caráter secundário em complementação às normas legais, com o objetivo de explicitá-las e dar-lhes execução. A regulação é uma função administrativa, que não decorre da prerrogativa do poder político, mas sim, da abertura da lei para que o agente regulador pondere, de forma neutra, os interesses concorrentes em conflitos setoriais, sejam eles potenciais ou efetivos (Moreira Neto, 2003:132-133).

Diante desses argumentos, a competência normativa exercida pelas entidades reguladoras, inserida no sistema de separação de poderes e considerando-se a proeminência da instituição legislativa para a positivação das regras jurídicas ("legalidade formal axiológica, legalidade material leve ou legalidade principiológica"), ${ }^{16}$ é inconfundível com o "poder regulamentar" primário, de competência do chefe do Poder Executivo.

Toda essa construção doutrinária chamada, por alguns, de escola pós-moderna para sustentar a constitucionalidade da normatização pelas agências reguladoras se atém à necessidade de equilíbrio sistêmico de setores regulados, impondo-se uma maleabilidade normativa inerente ao direito administrativo econômico.

Inserido no universo das escolhas administrativas, um dos fatores preponderantes que emerge em decorrência de toda essa transformação está no fato de que o direito administrativo experimenta uma forte influência do direito econômico

\footnotetext{
${ }^{15}$ Diogo de Figueiredo Moreira Neto é taxativo: “Uma vez operada a deslegalização, a regulação, como produção normativa decorrente, não se confunde com as normas de regulamentação editadas pelo Poder Executivo e, muito menos, com as normas emanadas das Casas Legislativas" (Moreira Neto, 2006:400).

${ }^{16}$ Cf. Aragão (2007:335).
} 
(despontando o "direito administrativo econômico"), sendo mais um componente de provocação, com grande pujança, do estudo da normatização feita por meio da regulação jurídica e os impactos, custos e benefícios da escolha regulatória protagonizada por entidades estatais independentes.

Há noções próprias do direito econômico que o direito administrativo não convivia nas relações entre o Estado e a sociedade.

As regras legais, para satisfazerem a necessidade de maior maleabilidade da matéria econômica, são, cumulativamente, menos imperativas, instáveis e imprecisas que as escolhas administrativas clássicas. Segundo Laubadère (1985:114), a flexibilidade inerente ao direito administrativo econômico traduz-se pelo lugar dado às possibilidades de mudança e de adaptação de regras, atos, situações jurídicas: "Mutabilidade, plasticidade, direito móvel ou flexível ou movediço, estas expressões são vulgarmente empregadas para caracterizar um dos aspectos [...] da maleabilidade do direito administrativo econômico".

Uma agência reguladora que tem o dever de manter o equilíbrio sistêmico, a exemplo dos serviços públicos de energia elétrica, transportes ou mesmo telecomunicações, precisa conviver com essa maleabilidade normativa primária (ou, na dicção de Marçal Justen Filho [2006:460], um "regramento dinâmico"), sob pena de ficar travada, não ter mecanismos para proteger o subsistema regulado.

No caso da Anvisa, como dito, em relação à indústria do tabaco, a hipótese é diversa, haja vista tratar-se de atuação fiscalizatória, normativa e sancionatória para o exercício, apenas, no âmbito do poder de polícia estatal descentralizado sobre determinadas atividades econômicas privadas (ainda que reforçado).

A regulação desenvolvida pela Anvisa sobre a indústria do tabaco não se enquadra na ideia de haver imperiosa regulação estatal descentralizada, contra barreiras às pressões políticas e sociais, estruturada para promover o equilíbrio sistêmico.

A Anvisa não carece de maleabilidade de normas legiferantes (para alguns, a denominada delegação normativa inominada) para agir e coibir os excessos eventualmente cometidos pelos agentes regulados. Nesse importante setor não se deve desconsiderar os possíveis e sérios problemas para a saúde que impõem uma atuação estatal atenta e célere; mas, data maxima venia, não pode ser considerado um risco sistêmico como vem ocorrendo, atualmente, no mercado financeiro estadunidense e como já ocorreu, entre nós, no período em que houve racionamento de energia elétrica, mais conhecido como "apagão".

O poder de polícia sanitária, exercido pela Anvisa de maneira reforçada sobre a indústria do tabaco que, por esta forma, regula e coordena essa atividade, é, a seu turno, disciplinado pela norma de direito, que, definindo o limite de competência da autoridade, repele e torna ilícito o abuso ou desvio de poder, interditando excessos, a irrazoabilidade, a desproporcionalidade e a arbitrariedade. 
A função de polícia sanitária e de salubridade é uma das primeiras atividades realizadas pelo Estado para assegurar a sua existência na ordem interna e na ordem externa. Polícia, em seu sentido amplo, significa o exercício de Poder Público sobre homens e coisas, com a finalidade de defender a ordem interna. A atividade de polícia - que não se confunde com a regulação sistêmica - abrange atividades da administração, quer para prevenir os males e as desordens da sociedade, quer para zelar pelo bem-estar físico, econômico, intelectual da população (Cretella Júnior, 1968:15).

Sobre essa diferença entre poder de polícia e regulação, colhe-se a advertência de Marçal Justen Filho (2006:461):

Na concepção clássica, o poder de polícia era visto como competência estatal orientada a reprimir o exercício de faculdades privadas, visando a assegurar a ordem pública. A regulação é um estágio posterior nessa evolução, em que o Estado restringe a autonomia dos particulares, visando a constrangê-los ou a induzi-los a produzir as condutas reputadas como socialmente úteis ou indispensáveis.

Rafael Bielsa (1939:1) leciona que poder de policía é "el conjunto de servicios organizados por la Administración pública con el fin de asegurar el orden público y garantizar la integridad física, y aun moral, de las personas, mediante limitaciones impuestas a la actividad individual y colectiva de ellas". O poder de polícia é assim um poder instrumental da administração pública para condicionar e restringir os possíveis abusos do particular em relação ao Estado e, consequentemente, à coletividade.

De fato, a sociedade em que vivemos goza de um regime de liberdades, assegurando aos cidadãos os seus direitos individuais, constitucionalmente protegidos. Com efeito, o exercício de direitos e liberdades individuais não pode, igualmente, ser entendido como tendo um caráter absoluto e deve ser interpretado de forma compatível com os interesses gerais da sociedade juridicamente organizada.

Por ter o Estado avocado para si a obrigação de manter incólume os direitos individuais, tornou-se indispensável o uso do poder de polícia para disciplinar os aspectos da vida social e dotar a administração pública de ferramentas para restringir o direito e proibir o abuso. Bem por isso, há necessidade de que os "direitos-liberdades" sejam assegurados e regulamentados pelo Estado, de forma que este passe a gozar de coercibilidade, como lecionam Jean-Marie Bécet e Daniel Colard (1985:25), in verbis:

Pour qu'une liberte publique existe, elle doit être «nommée» dans l'odre juridique positif. Pout qu'elle soit réelle et que l'Etat remplisse effectivemente sés «devoirs juridiques», cet ordre doit être cohérent et comporter des instituitions ou des mé- 
canismes qui assurent préventivement le respect des droits et libertés. La garantie juridique des libertes publiques dans la tradition libérale repose sur la proclamation des droits fondamentaux par la Constituition, l'organisation des libertés publiques par le législateur et l'affirmation des principes généraux du droit par le Conseil D'Etat et le Conseil Constitutionnel.

Nessa ordem de convicções torna-se oportuna a transcrição sempre valiosa da lição de Marcello Caetano, ao doutrinar sobre o estudo desse tema, em que assevera:

A polícia é actuação da autoridade, pois pressupõe o exercício de um poder condicionante de actividades alheias, garantido pela coação sob a forma característica da Administração, isto é, por execução prévia. É uma intervenção no exercício de actividades individuais e a possibilidade da sua violação por estes. [...] A polícia intervém nas actividades individuais de fazer perigar interesses gerais. Só aquilo que constitua perigo susceptível de projectar-se na vida pública interessa à Polícia, e não o que apenas afecte interesses privados ou a intimidade das existências pessoais.

Nesse sentido, a Anvisa detém poder de polícia sanitária, que consiste em um conjunto de intervenções para disciplinar a atuação, entre outras, da indústria do tabaco, objetivando prevenir ou reprimir perturbações à saúde pública. Assim, a Anvisa deve, de acordo com os limites da lei:

condicionar o exercício de direitos individuais;

delimitar a execução de atividades;

$>$ condicionar o uso de bens que afetem a coletividade ou contrariem a ordem jurídica estabelecida ou se oponham aos objetivos permanentes da nação nos limites constitucionais.

Esse pensamento está alinhado com a decisão do Egrégio Superior de Justiça, no acórdão proferido nos autos do Resp. 906.175, em que foi relator o ministro Castro Meira, em julgado publicado no Diário Oficial do dia 24 de junho de 2008. O caso foi julgado em uma ação declaratória, com pedido de tutela antecipada, ajuizada com o objetivo de ver declarado o direito de a parte autora importar e requerer autorização de importação de substâncias controladas que lhe servem de matéria-prima (heliotropina, substância química utilizada como fixador de aromas, retirada do óleo de sassafrás), sem que tenha que observar os prazos para importação previstos na Portaria no 34498, da Secretaria de Vigilância Sanitária do Ministério da Saúde (arts. 11, 12, 14, 15 e 17). 
Sustentou a parte autora que a Agência Nacional de Vigilância Sanitária (Anvisa) limitou a importação do produto (óleo de sassafrás) a oito meses por ano, fato que lhe acarreta inúmeros prejuízos, além não encontrar previsão legal. Nesse sentido, entendeu ser ilegal a portaria, impondo restrições não previstas em lei, com o que requereu fosse julgado procedente o pedido.

Deu-se provimento à apelação em $2^{\underline{o}}$ grau - posteriormente reformada pelo STJ - decidindo-se pela inconstitucionalidade da Resolução Anvisa por extrapolar a lei e inviabilizar a atividade da empresa recorrente, nos termos do seguinte acórdão:

ADMINISTRATIVO. SECRETARIA DE VIGILÂNCIA SANITÁRIA. PORTARIA 34498. PRAZOS PARA IMPORTAÇÃO. PODER REGULAMENTAR QUE EXTRAPOLA A LEI. A adoção de prazos procedimentais pela agência, exceto no que diz com o pedido de importação e requerimento de autorização, extrapola o poder concedido pelo legislador, bem ainda, inviabiliza o exercício da atividade da empresa importadora.

Admitido o apelo, subiram os autos ao Superior Tribunal de Justiça, que decidiu no sentido de que não houve ilegalidade na expedição da norma à luz do poder de polícia, in verbis:

ADMINISTRATIVO. PROCEDIMENTO PARA IMPORTAÇÃO PELA ANVISA. SUBSTÂNCIA PRECURSORA DE DROGAS ILÍCITAS. LEGALIDADE. 1. Não há eivas de ilegalidade na Portaria 34498, com a redação da RDC 22901, que obriga a empresa importadora a solicitar à Secretaria de Vigilância Sanitária do Ministério da Saúde a fixação de Cota Anual de Importação de substâncias constantes das listas "A1" e "A2" (entorpecentes), "A3", "B1" e "B2" (psicotrópicas) e "D1" (precursoras), até 30 de novembro de cada ano, para uso no ano seguinte. 2. Recurso especial provido.

Diante do exposto, é plausível inferir, em tese, a juridicidade na competência outorgada por lei à Anvisa para expedir normas. Essa competência não se enquadra na fórmula da discricionariedade, administrativa ou técnica. Há necessidade jurídica de que as normas afetas ao direito econômico sejam maleáveis (soft law) quando da regulação de subsistemas sujeitos a riscos sistêmicos. A Anvisa não se enquadra no modelo de regulação sistêmica ao exercer o poder de polícia sobre a atividade da indústria do tabaco. Assim, considera-se regular, em tese, o exercício do poder de polícia sanitária da Anvisa, desde que esteja de acordo com o disposto no parágrafo único do art. 78 do CTN, isto é, desde que o desempenho o seja nos limites da lei aplicável, com observância do processo legal, dos princí- 
pios da razoabilidade e da proporcionalidade e, tratando-se de atividade que a lei tenha conceitos jurídicos indeterminados e atribua discricionariedade, sem abuso ou desvio de poder.

\section{As escolhas administrativas da Anvisa como executora de políticas de controle do tabagismo e seus limites. Os excessos e desvios cometidos pela RDC nำ54, da Anvisa, sob uma visão pós-positivista do princípio da legalidade e da teoria de "deslegalização" de matérias técnicas para entidades estatais descentralizadas}

Após o exame de todos os aspectos supra, passa-se a examinar a juridicidade da RDC nº 54, de 6 de agosto de 2008, da Agência Nacional de Vigilância Sanitária (Anvisa). Isto é, se essa normativa se enquadra nos limites da competência outorgada pelo texto legal para o exercício do poder de polícia ou se, ao contrário, a "escolha" da Anvisa extrapolou a sua competência e usurpou competência legiferante.

Por meio dessa normativa (RDC no 54), a Anvisa determinou sejam adotadas pela indústria do tabaco novas imagens e frases de advertência nas embalagens de produtos derivados de tabaco.

Essa regra foi publicada no Diário Oficial da União do dia 7 de agosto de 2008 e, assim, as frases de advertência e imagens deverão ser usadas de forma simultânea ou rotativa e a consulente não poderá manter a mesma frase e ilustração por mais de cinco meses. Desse modo, a consulente terá alguns meses, a contar da data da publicação, para adaptar embalagens e materiais de propaganda à nova normatização.

Segundo divulgado pela Anvisa na imprensa, as fotos e mensagens foram produzidas com base em um estudo acerca do grau de aversão que as ilustrações alcançam.

O Brasil adotou a política de impor a colocação de imagens de advertência em carteiras de cigarros como estratégia para diminuir a prevalência e evitar a experimentação do cigarro por jovens e adolescentes. Desde 2001, os fabricantes de produtos de tabaco são obrigados, por lei (e não apenas por força de resolução da Anvisa), a inserirem advertências sanitárias ilustradas com fotos.

A base constitucional para essa determinação governamental encontra-se, genericamente, no disposto no art. 220 da Carta de 1988, in verbis:

Art. 220. A manifestação do pensamento, a criação, a expressão e a informação, sob qualquer forma, processo ou veículo não sofrerão qualquer restrição, observado o disposto nesta Constituição. 
$\S 1^{\circ}$ Nenhuma lei conterá dispositivo que possa constituir embaraço à plena liberdade de informação jornalística em qualquer veículo de comunicação social, observado o disposto no art. 5ํㅡ, IV, V, X, XIII e XIV.

$\S 2^{\circ}$ É vedada toda e qualquer censura de natureza política, ideológica e artística.

§3o Compete à lei federal:

II - estabelecer os meios legais que garantam à pessoa e à família a possibilidade de se defenderem de programas ou programações de rádio e televisão que contrariem o disposto no art. 221, bem como da propaganda de produtos, práticas e serviços que possam ser nocivos à saúde e ao meio ambiente.

$\S 4^{\mathrm{o}}$ A propaganda comercial de tabaco, bebidas alcoólicas, agrotóxicos, medicamentos e terapias estará sujeita a restrições legais, nos termos do inciso II do parágrafo anterior, e conterá, sempre que necessário, advertência sobre os malefícios decorrentes de seu uso.

Nesse contexto jurídico-constitucional foi editada a Lei no 9.294, de 15 de julho de 1996, que dispôs sobre as restrições à propaganda de produtos fumígenos. Vê-se que o constituinte outorgou margem de discricionariedade na edição do ato legislativo ao se valer de um conceito jurídico indeterminado ("sempre que necessário") para que o legislador ordinário deliberasse acerca desses limites.

Interessa destacar nessa norma, para efeito de chegar-se a algumas conclusões sobre as indagações apresentadas pela consulente, os seguintes dispositivos da Lei nº 9.294, de 15 de julho de 1996:

Art. 1‥ O uso e a propaganda de produtos fumígeros, derivados ou não do tabaco, de bebidas alcoólicas, de medicamentos e terapias e de defensivos agrícolas estão sujeitos às restrições e condições estabelecidas por esta Lei, nos termos do $\$ 4^{\mathrm{o}}$ do art. 220 da Constituição Federal.

Art. 3․ A propaganda comercial dos produtos referidos no artigo anterior só poderá ser efetuada através de pôsteres, painéis e cartazes, na parte interna dos locais de venda. (Redação dada pela Lei n⿳0 10.167 , de 27-12-2000)

$\S 1^{\circ}$ A propaganda comercial dos produtos referidos neste artigo deverá ajustar-se aos seguintes princípios:

I - não sugerir o consumo exagerado ou irresponsável, nem a indução ao bem-estar ou saúde, ou fazer associação a celebrações cívicas ou religiosas; II - não induzir as pessoas ao consumo, atribuindo aos produtos propriedades calmantes ou estimulantes, que reduzam a fadiga ou a tensão, ou qualquer efeito similar; 
III - não associar ideias ou imagens de maior êxito na sexualidade das pessoas, insinuando o aumento de virilidade ou feminilidade de pessoas fumantes;

IV - não associar o uso do produto à prática de atividades esportivas, olímpicas ou não, nem sugerir ou induzir seu consumo em locais ou situações perigosas, abusivas ou ilegais. (Redação dada pela Lei no 10.167, de 27.12.2000)

$\mathrm{V}$ - não empregar imperativos que induzam diretamente ao consumo;

VI - não incluir a participação de crianças ou adolescentes. (Redação dada pela Lei no 10.167 , de 27.12.2000)

\$2 A propaganda conterá, nos meios de comunicação e em função de suas características, advertência, sempre que possível falada e escrita, sobre os malefícios do fumo, bebidas alcoólicas, medicamentos, terapias e defensivos agrícolas, segundo frases estabelecidas pelo Ministério da Saúde, usadas sequencialmente, de forma simultânea ou rotativa. (Redação dada pela Medida Provisória no 2.190-34, de 2001)

\$3 $3^{\circ}$ As embalagens e os maços de produtos fumígenos, com exceção dos destinados à exportação, e o material de propaganda referido no caput deste artigo conterão a advertência mencionada no $§ 2^{\circ}$ acompanhada de imagens ou figuras que ilustrem o sentido da mensagem. (Redação dada pela Medida Provisória nº 2.190-34, de 2001)

$\S 4^{\circ}$ Nas embalagens, as cláusulas de advertência a que se refere o $\S 2^{\circ}$ deste artigo serão sequencialmente usadas, de forma simultânea ou rotativa, nesta última hipótese devendo variar no máximo a cada cinco meses, inseridas, de forma legível e ostensivamente destacada, em uma das laterais dos maços, carteiras ou pacotes que sejam habitualmente comercializados diretamente ao consumidor.

$\S 5^{\circ}$ A advertência a que se refere o $\$ 2^{\circ}$ deste artigo, escrita de forma legível e ostensiva, será sequencialmente usada de modo simultâneo ou rotativo, nesta última hipótese variando, no máximo, a cada cinco meses. (Redação dada pela Lei $\mathrm{n}^{\mathrm{o}}$ 10.167, de 27.12.2000)

Podem ser constatadas algumas premissas nessa norma legal para a análise do caso concreto.

Com efeito, salvo com relação ao $\$ 2^{\circ}$ do art. $3^{\circ}$, que atribui discricionariedade ao Ministério da Saúde na escolha das frases ("segundo frases estabelecidas pelo Ministério da Saúde"), as demais disposições são vinculadas para a administração pública direta e indireta. Basta ver os comandos empregados pelo legislador ordinário na mencionada regra legal: "estão sujeitos a esta lei", "será", "conterão", "serão" etc. 
No ato vinculado, segundo as lições de García de Enterría e Fernandéz (2001:435), o fim legal apresenta-se tendo uma objetividade incondicional e unívoca, de modo que o comportamento da administração pública, além de demandado em situações especialíssimas, é exatamente determinado pela lei.

Poder-se ia argumentar - a favor de uma leitura aberta do princípio oitocentista da legalidade - que por estarmos vivendo na pós-modernidade haveria que se cogitar, na espécie, a ideia de uma nova fase do direito na qual se destaca o póspositivismo; isto é, a ideia de que o Poder Legislativo não consegue editar normas sobre todos os fatos que se seguem à intensa complexidade e tecnicidade cotidiana, trazendo ao debate, justamente, o importante papel das agências reguladoras na manutenção de equilíbrio sistêmico, inclusive por meio de normas regulatórias que, como dito, não se confundem com os regulamentos expedidos pelo chefe do Poder Executivo.

Na lição de Paulo Otero (2003:107-108):

A crescente complexificação das matérias e a impossibilidade de o parlamento dar resposta pronta e conveniente a todas as exigências de um modelo de Estado de bem-estar conduziram a uma progressiva assunção de poderes normativos por parte do executivo, incluindo a permanente feitura de actos com força de lei cuja prática pelo executivo a Constituição configurava como tendo uma natureza excepcional, podendo falar-se, num primeiro momento, em tentativa de fraude à Constituição e hoje, atendendo a reiterada prática e à ausência de qualquer sancionamento judicial, será possível defender-se formação de um costume constitucional contra constitutionem.

Esse pensamento, inclusive, vem sendo sustentado doutrinariamente por este signatário (Guerra, 2008) nos casos em que se impõe uma regulação estatal descentralizada para evitar-se a ingerência política nas questões em que as escolhas administrativas reflexivas devam ser preponderantemente técnicas para evitar-se o risco sistêmico, aliás, como vem decidindo o Poder Judiciário em diversos casos recentes, como os a seguir colacionados.

Vale trazer, inicialmente, a título ilustrativo, acórdão da $1^{\text {a }}$ turma do egrégio Superior Tribunal de Justiça, no agravo regimental na Medida Cautelar no 10.443/ $\mathrm{PB}$, em que funcionou como relator o ministro Francisco Falcão, no julgamento ocorrido em 13 de dezembro de 2005, publicado no Diário de Justiça de 6 de março de 2006. Consistiu em medida cautelar, com pedido de liminar, ajuizada pela TNL PCS S/A - OI, buscando atribuir efeito suspensivo ao recurso especial interposto contra o acórdão proferido em agravo de instrumento, o qual reverteu decisão que havia indeferido tutela antecipada em ação civil pública para acabar com a prescrição dos créditos do sistema de celulares pré-pago. 
O julgamento em questão levou em consideração o voto-vista do ministro Luiz Fux, que assim ementou sua decisão, enfrentando o tema da capacidade técnica das entidades reguladoras independentes para manter o equilíbrio do sistema regulado:

LIMINAR E TELEFONIA. SERVIÇO PRÉ-PAGO. DEFESA AO CONSUMIDOR. LEGITIMAÇÃO DO MINISTÉRIO PÚBLICO. RECURSO ESPECIAL ADMITIDO. CAUTELAR E EFEITO SUSPENSIVO. FUMUS BONI JURIS E PERICULUM IN MORA PRESENTES. ATUAÇÃO CONFORME ATO DA AGÊNCIA REGULADORA. 1. Vigente ato normativo da Agência Reguladora cujo escopo é regular o segmento, não podem os estabelecimentos regulados absorverem danos e punições pelo fato do cumprimento das regras maiores, posto engendrarem exercício regular do direito. 2. A modificação ex abrupto dessas regras da Agência Reguladora por tutela provisória em liminar concedida em ação acarreta periculum in mora, mercê de o fumus boni juris repousar no cumprimento do ato da Agência. 3. Deveras, somente a ausência de nulificação específica do ato da Agência autoriza o Judiciário a intervir no segmento, sob pena de invadir seara administrativa estranha ao Poder Judiciário. (Sérgio Guerra, in: Controle Judicial dos atos regulatórios, Editora Lumem Juris, Jan/2005, p. 355-369). 4. Ratio essendi dos precedentes da Corte Especial na análise de Suspensões de Segurança calcadas em atos das Agências e no princípio pacta sunt servanda. (Ag. Rg. na SL 57DF, rel. min. Edson Vidigal, DJ de 6-9-2004). 5. Impossibilidade de atendimento técnico da decisão liminar, que configurou para o Relator periculum in mora inverso, máxime porque a adoção da providência contrária ao ato da Anatel (art. 55 da Resolução 3162002, e itens 4.6 e 4.6.1, da Norma 0398). 6. Notória inversibilidade do provimento (art. 273, §5ํㅡㄹ do CPC), revelando-se prematura, em sede de liminar, alterar-se um quadro normativo complexo e idealizado pela Agência Reguladora, induzindo o Judiciário não só a invadir a seara administrativa exclusiva da Agência, como também a atuar como legislador positivo, em manifesta afronta à sedimentada jurisprudência da Corte Suprema. 7. Agravo Regimental provido, para deferir a medida liminar, acompanhando o E. Relator.

Merece destaque, nesse mesmo sentido e trazendo textualmente a ideia de risco sistêmico da questão regulatória, o aresto abaixo do egrégio Superior Tribunal de Justiça, in verbis: 
NACIONAL DE SAÚDE - ANS. 1. Considerados o alto interesse público envolvido, os efeitos prospectivos da medida, os riscos e resultados que conclusões açodadas possam ocasionar (desarmonia e desequilíbrio para o setor da saúde suplementar), deve ser deferido o pedido para suspender a decisão que concedeu o efeito modificativo ativo ao Agravo de Instrumento. 2. Lesão à saúde e à ordem pública administrativa caracterizada, com a interferência na legítima atividade regulatória desempenhada pela ANS, respaldada em discricionariedade técnica. 3. Agravo interno não provido. (Ag. Rg. na SLS 163/PE; Agravo regimental na suspensão de liminar e de sentença 2005/0128970-7, relator ministro Edson Vidigal. Órgão julgador: Corte Especial, data do julgamento 19.12.2005 e data da publicação/Fonte: DJ de 27-3-2006, p. 133.

Colhe-se ainda, pela relevância, o voto do relator:

Em que pese aos judiciosos argumentos expendidos e aos do Ministério Público Federal, e sem adentrar no mérito da questão relativa ao critério utilizado para alcançar o índice adotado para o reajuste dos contratos antigos, tenho que a decisão liminar pode causar lesão grave à ordem pública administrativa, na medida em que interfere na legítima atividade regulatória desempenhada pela ANS, com respaldo na discricionariedade técnica, gerando, também, instabilidade no mercado de saúde suplementar. Não se trata de ato flagrantemente ilegal e, em assim sendo, ao Judiciário não é dado adentrar no mérito das normas e procedimentos regulatórios, sob pena de estar invadindo seara alheia. Nesse sentido, mudando o que deve ser mudado, se a prestadora de serviços deixa de ser devidamente ressarcida dos custos e despesas decorrentes de sua atividade, não há, pelo menos no contexto das economias de mercado, artifício jurídico que faça com que esses serviços permaneçam sendo fornecidos com o mesmo padrão de qualidade. [...] Esse o enfoque dado à matéria por Sérgio Guerra, em Controle judicial dos atos regulatórios, anotando que: "se o julgador alterar um ato administrativo regulatório, que envolve, fundamentalmente, a eleição discricionária dos meios técnicos necessários para o alcance dos fins e interesses setoriais - despido das pressões políticas comumente sofridas pelos representantes escolhidos pelo sufrágio - , esse magistrado, na maioria das vezes, poderá, por uma só penada, afetar toda a harmonia e equilíbrio de um subsistema regulado" (2005, fls. 272/275).

Contudo, e para aprofundar o debate em torno do espinhoso tema dos limites da atuação da Anvisa, no caso concreto, poder-se-ia argumentar, à luz dessa nova doutrina e em favor dessa normativa da Anvisa, que em vista da relativização do princípio da legalidade - um dos principais aspectos suscitados pela doutri- 
na contemporânea, relativamente à transformação do direito público - a RDC n 54/2008 poderia decorrer da impossibilidade de a lei (Lei nº 9.782, de 26 de janeiro de 1999) indicar todos os limites em termos de vigilância sanitária, o que se adaptaria à teoria do pós-positivismo ou, até mesmo, corresponderia a uma forma de "deslegalização" de matérias técnicas para entidades do Poder Executivo.

Segundo lição de Luís Roberto Barroso (2006:43-92), o marco filosófico do novo direito constitucional é o pós-positivismo. O debate acerca de sua caracterização situa-se na confluência das duas grandes correntes de pensamento que oferecem paradigmas opostos para o direito: o jusnaturalismo e o positivismo. Opostos, mas, por vezes, singularmente complementares. A quadra atual é assinalada pela superação - ou, talvez, sublimação - dos modelos puros por um conjunto difuso e abrangente de ideias, agrupadas sob o rótulo genérico de pós-positivismo. O jusnaturalismo moderno, desenvolvido a partir do século XVI, aproximou a lei da razão e transformou-se na filosofia natural do direito. Fundado na crença em princípios de justiça universalmente válidos, foi o combustível das revoluções liberais e chegou ao apogeu com as constituições escritas e as codificações. Considerado metafísico e anticientífico, o direito natural foi empurrado para a margem da história pela ascensão do positivismo jurídico, no final do século XIX. Em busca de objetividade científica, o positivismo equiparou o direito à lei, afastou-o da filosofia e de discussões como legitimidade e justiça e dominou o pensamento jurídico da primeira metade do século XX. Sua decadência é emblematicamente associada à derrota do fascismo na Itália e do nazismo na Alemanha, regimes que promoveram a barbárie sob a proteção da legalidade. Ao fim da Segunda Guerra, a ética e os valores começam a retornar ao direito. A superação histórica do jusnaturalismo e o fracasso político do positivismo abriram caminho para um conjunto amplo e ainda inacabado de reflexões acerca do direito, sua função social e sua interpretação.

De acordo com a sua doutrina, o pós-positivismo busca ir além da legalidade estrita, mas não despreza o direito posto. Procura empreender uma leitura moral do direito, mas sem recorrer a categorias metafísicas.

A interpretação e a aplicação do ordenamento jurídico hão de ser inspiradas por uma teoria de justiça, mas não podem comportar voluntarismos ou personalismos.

No conjunto de ideias ricas e heterogêneas que procuram abrigo nesse paradigma em construção incluem-se a atribuição de normatividade aos princípios e a definição de suas relações com valores e regras; a reabilitação da razão prática e da argumentação jurídica; a formação de uma nova hermenêutica constitucional; e o desenvolvimento de uma teoria dos direitos fundamentais edificada sobre o fundamento da dignidade humana. Nesse ambiente, promove-se uma reaproximação entre o direito e a filosofia.

Não se nega neste parecer o entendimento do signatário de que o princípio da legalidade encontra-se em evolução. Há um debate em curso nos meios acadêmicos, notadamente em vista das teorias que incluíram os princípios como normas: 
"Principles have a dimension of weight or importance. When principles intersect [...] one who most resolve the conflict has to take into account the relative weight of each" (Dworkin, 1998:26).

No contexto em que foi concebida a noção clássica do princípio da legalidade em relação ao Poder Público, aos agentes públicos somente seria facultado agir por autorização ou imposição legal. Na ausência do comando legal "autorizativo", não existiria atuação administrativa legítima. Em uma palavra: à administração pública somente seria dado atuar tendo a lei por fundamento, sendo-lhe vedados os atos não autorizados em algum texto legal.

Por oportuno, convém ressaltar que, em seu viés "jusprivatístico", o princípio da legalidade apresentava - e ainda apresenta - conteúdo distinto: traduz-se na prerrogativa assegurada aos particulares de fazer tudo aquilo que a lei não proíbe. Trata-se de garantia do direito de liberdade, materializada no inciso II do art. 5o da CRFB/88 nos seguintes termos: "ninguém será obrigado a fazer ou deixar de fazer alguma coisa senão em virtude de lei".

Há que se frisar que o objetivo liberal do império absoluto da lei e da consequente submissão absoluta da administração à lei nunca foram efetivamente alcançados em função de fenômeno ao qual se convencionou chamar de "crise da lei formal". Deveu-se tal crise, em primeiro lugar, à (hoje amplamente) consolidada noção da incompletude intrínseca às leis, impotentes e incapazes que são para estabelecer, a priori e de maneira exaustiva, todos os atos que o administrador (e, no caso, o regulador) deverá praticar de modo a atender o interesse público.

Em virtude de tal constatação, impôs-se ao legislador que, na impossibilidade de prever todas as situações que exigiriam a atuação do Poder Público, conferisse certa margem de liberdade à administração na determinação do conteúdo dos preceitos legais. Assim, em técnica legislativa intitulada de discricionariedade, passaram as leis a ser menos determinadas e mais gerais. ${ }^{17}$

A segunda razão passível de ser apontada por parte da doutrina para a crise da lei e do próprio princípio da legalidade é o fato de terem sido concedidas funções normativas à administração pública com a finalidade de que, ela própria - e não mais apenas o Poder Legislativo - , passasse a estabelecer normas jurídicas. Esse fenômeno, já verificado sob a égide do próprio Estado mínimo liberal, ganha fôlego e tem sua importância multiplicada com o Estado social, inicialmente gestor de uma série de atividades econômicas e, nos últimos tempos, preponderantemente regulador de tais atividades.

\footnotetext{
${ }^{17}$ Nesse sentido, Aragão (2001:116).
} 
Assiste-se, portanto, na atualidade, à proliferação de uma série de atos normativos infraconstitucionais distintos da lei em sentido formal, a exemplo das resoluções da Anvisa.

Especificamente na sistemática da CRFB/88, os seguintes fenômenos podem ser apontados como ilustrativos desse segundo fator determinante da crise da lei: a criação de amplo espaço normativo primário para o Poder Executivo, que pode editar atos com força de lei, quais sejam, as medidas provisórias e as leis delegadas (arts. 62 e 68); o estabelecimento de campo regulamentar autônomo ao Poder Executivo, que passa a dispor - mesmo na ausência de lei - sobre a organização e o funcionamento da administração pública, desde que de sua atividade regulamentadora não resulte aumento de despesa, nem criação ou extinção de órgãos públicos (art. 84, VI, a). Adicionalmente, muitas vezes a própria lei se furta a dispor de maneira minuciosa sobre determinadas matérias, deixando ao regulamento do presidente da República (art. 84, IV, CF) largo campo de conformação (Binenbojm, 2006:134).

Algumas causas poderiam ser apontadas como fundamentos da concessão de funções normativas à administração pública. Entretanto, para os fins do presente parecer, basta afirmar que a crescente complexidade das relações sociais e econômicas que demandavam e ainda hoje demandam uma ordenação imediata por parte do Estado não se coaduna com a lentidão e a generalidade do processo legislativo tradicional, como, aliás, decidiu o STJ no Resp. 906.175, transcrito supra quase que literalmente.

Bermejo Vera (2005:25), ao comentar sobre esse novo direito suave (soft law), preconiza:

Que tratan de recoger aquellas especificaciones basadas en la ciencia, la experiencia o la tecnología necesarias o convenientes para concretar características de los bienes y productos de las actividades industriales. Estas normas técnicas ofrecen una doble dimensión. Por una parte, hay normas de aplicación voluntaria. Pero, por otro lado, existen reglamentaciones técnicas de naturaleza obligatoria. Son en todo caso respuestas al desarollo tecnológico y, aunque diferenciadas en su origen, estructura y efectos, las reglamentaciones técnicas poseen una extraordinaria importancia en el momento actual.

Com efeito, formulado como uma consequência necessária e indissociável do ideário liberal oitocentista do império da lei e da supremacia do Legislativo - segundo o qual a tarefa do Executivo e da administração pública seria, tão somente, a de cumprir os desígnios da vontade popular expressa através das leis - o princípio da legalidade, tal como então concebido, tem dificuldade em se sustentar. Necessita de uma imprescindível releitura contemporânea à luz da supremacia 
formal e axiológica da Constituição e dos demais fatores da crise da lei formal assim enunciados. Caso típico ocorreu no julgamento da $\operatorname{ADI}^{\text {o }}$ 3.395, em que o Supremo Tribunal Federal julgou pela constitucionalidade da Resolução $n^{0} 7$ do Conselho Nacional de Justiça, que decidiu, apenas com fulcro nos princípios do art. 37 da Constituição Federal de 1988 (e não em lei), pela ausência de juridicidade na prática do nepotismo.

Assim, o signatário do presente parecer se filia à doutrina que sustenta que a legalidade deve, correntemente, ser compreendida como uma vinculação da administração e de sua atuação à juridicidade, i.e., ao ordenamento jurídico em sua unidade. Deve estar em sintonia ao bloco de legalidade que integra e conforma o ordenamento jurídico (Constituição, leis ordinárias, leis complementares, leis delegadas, medidas provisórias, regulamentos gerais e regulamentos setoriais).

Contudo, mesmo diante dessa patente crise legalitária, a lei deve ser considerada, haja vista que não deixa de ser o padrão a ser observado pela administração pública (especialmente a Anvisa, ao exercer o poder de polícia sanitária) e toda a sociedade. A lei geral, mesmo diante do pós-positivismo, deve ser, na maioria dos casos, a fonte preferencial como ponto de partida para a atual função administrativa (Otero, 2003:27).

Esse aspecto da questão é didaticamente focalizado pelo jurista português Cabral de Moncada (2002:315).

A reserva da lei continua, portanto, a ter uma função garantística essencial. É esse o seu sentido principal, sem esquecer que ela é também um elemento fundamental de um sistema democrático de base parlamentar. A única coisa que perdeu foi a capacidade de claramente distinguir a esfera do direito da irrelevância jurídica, melhor dizendo: se o critério subjetivista que presidia à reserva de lei tradicional era um critério seguro, relativamente rígido e pouco susceptível de variações na sua extensão, o mesmo se não passa hoje, pois que o critério que a identifica é variável e foi mesmo pensado para o ser, susceptível de um escalonamento entre um máximo e um mínimo e só assim compreensível e utilizável, pelo que não pode ter a pretensão de fornecer de uma vez por todas, sem margem para dúvidas, a lista de todo o material que carece de disciplina legislativa. Do critério moderno de reserva de lei, de que a teoria da essencialidade é a síntese mais feliz, não transparece imediatamente todo o mostruário da relevância jurídico-legislativa. É por isso que ele é um critério aberto e pluralista. Aberto porque há nele lugar para o compromisso político entre as forças actuantes na sociedade e no estado, assumindo a abertura, precisamente a forma, de um compromisso variável entre visões políticas diversas com diferente força de pressão, mas aspirando cada uma delas a deixar a sua marca na disciplina normativa a 
eleger e no catálogo de assuntos a escolher, que podem ir desde a maior repressão da criminalidade ao segredo bancário, desde a protecção do ambiente à emigração estrangeira etc. [...] Pluralista porque a matriz axiológica a requerer disciplina legislativa há muito que virou costas aos problemas e aspirações do indivíduo isolado e à questão de protecção da sua liberdade e propriedade subjectivas.

É primorosa, nesse aspecto, a manifestação de Luís Roberto Barroso (2004:317):

A redemocratização no Brasil impulsionou uma volta ao Direito. É certo que já não se alimenta a crença de que a lei seja "a expressão da vontade geral institucionalizada" e se reconhece que, frequentemente, estará a serviço de interesses, e não da razão. Mas ainda assim ela representa a despersonalização do poder e a institucionalização da vontade política. O tempo das negações absolutas passou. Não existe compromisso com o outro sem a lei.

Portanto, mesmo diante de toda essa evolução e mutação do direito público e a alegada "crise" do princípio da legalidade, e em se admitindo juridicamente que há espaço para que a Anvisa edite regras diante da incapacidade material de o Parlamento prever todas as hipóteses a serem disciplinadas pelas normas primárias (Lei no 9.782, de 26 de janeiro de 1999), de fato não poderia a Anvisa editar norma (RDC $n^{0}$ 54/2008) que contrarie a escolha pública definida pelo constituinte e pelo legislador ordinário em termos de propaganda dos produtos produzidos pela indústria do tabaco.

Questão similar ao tema foi submetida recentemente à Advocacia-Geral da União, quando a Anvisa pretendeu editar resolução para disciplinar a propaganda de bebida alcoólica. Com efeito, a diretoria colegiada da Anvisa acreditava que possuía competência para alterar o conceito de bebidas alcoólicas para restringir as propagandas desses produtos por meio de uma resolução normativa, que trata das "restrições ao uso e à propaganda de produtos fumígeros, bebidas alcoólicas, medicamentos, terapias e defensivos agrícolas" e também pela lei. A Anvisa se baseava na Lei no 9.782, de 26 de janeiro de 1999 - lei de sua criação, e que outorga competência para edição de normas regulatórias, adiante examinada neste parecer.

A consulta foi formulada nos seguintes termos:

Senhor Consultor-Geral,

Atendendo a sugestão de Vossa Senhoria, indago sobre a legalidade de uma possível resolução da Anvisa que restringisse a propaganda de bebidas al- 
coólicas com teor abaixo de $13^{\circ}$ Gay Lussac, em face do disposto na Lei ํㅡㄴ 9.294/1996 e no Decreto no 6.117/2007.

Atenciosamente,

Dirceu Raposo de Mello - Diretor-Presidente

Instada, então, formalmente pela Anvisa sobre sua competência para dispor sobre a matéria, a Advocacia-Geral da União, por meio da Nota N. AGU/GV16/2007, nos autos dos processos nos 00400.001339/2007-03 e 00400.001244/2007-81, tendo como interessados não somente a Agência Nacional de Vigilância Sanitária, mas também o Conar, concluiu que apenas um projeto de lei elou uma medida provisória podem alterar o conceito de bebidas alcoólicas para restringir as propagandas desses produtos, nos seguintes termos:

VII - Sem embargo de entender absolutamente correta, no mérito, a atualização do conceito de bebida alcoólica contido no anexo I do Decreto em causa - já que a tecnologia atual permite a fabricação de vinhos e cervejas, sem alteração de sabor, não apenas com menos de 0,5 grau de teor alcoólico, mas até com teor rigorosamente zero - do ponto de vista jurídico é necessário que o novo conceito não fique apenas no anexo I do Decreto, mas passe a ser a nova redação do parágrafo único do art. 1o da Lei 9.294, de 15 de julho de 1996, sem o que a discrepância entre os dois dispositivos ensejará procedimento judicial que a petição do CONAR já insinua.

A hipótese submetida à AGU para as bebidas alcoólicas, como no caso do presente parecer, exige tratamento por meio de lei (reserva absoluta da lei). Nas palavras do ilustre jurista carioca Gustavo Binenbojm (2003:137-168), em artigo específico sobre a publicidade na indústria do tabaco:

a hipótese em tela está submetida à reserva absoluta da lei, porquanto toda a matéria relativa à restrição da atividade de comunicação das empresas de cigarro deve estar contida na lei, não existindo a possibilidade de transpasse, ainda que parcial, desta competência normativa reservada ao Legislativo a órgão da Administração.

Veja-se que o parecer supra da AGU foi submetido ao consultor-geral da União (Despacho no 249/2007) que, de forma expressa, afirmou que a questão está submetida à reserva absoluta da lei. In verbis:

1. Estou de acordo com a NOTA № AGU/GV - 16/2007, de autoria do Consultor da União, Dr. Galba Velloso, que dirime as dúvidas de natureza jurí- 
dico-constitucional formuladas, de parte a parte, pela Anvisa e pelo Conar, no que concerne à constitucionalidade e à legalidade de eventual resolução da Anvisa que restringisse a propaganda de bebidas alcoólicas.

2. As dúvidas são suscitadas a partir dos conceitos de bebidas alcoólicas previstos, de forma contraditória, no parágrafo único do art. $1^{\underline{0}}$ da Lei $\mathrm{n}^{\mathrm{o}}$ 9.294, de 1996, e no item III do Anexo I do Decreto no 6.117, de 2007, que aprova a Política Nacional sobre o álcool.

3. Tal definição possui extrema relevância, pois está diretamente relacionada à disciplina de propaganda de bebidas alcoólicas de que trata o art. $4^{\circ}$ da Lei no 9.294, de 1996, que abrange, inclusive, o horário de sua veiculação pelas emissoras de rádio e de televisão.

4. Parece-me correta a posição do douto Consultor ao afirmar que somente por lei ou medida provisória pode o conceito de bebidas alcoólicas, previsto no parágrafo único do art. $1^{\underline{o}}$ da Lei $n^{\circ}$ 9.294, de 1996, ser alterado.

5. É o que se extrai da dicção do $\S 4^{\circ}$ do art. 220 da Constituição Federal que determina que "a propaganda comercial de tabaco, bebidas alcoólicas, agrotóxicos, medicamentos e terapias, estará sujeita a restrições legais, nos termos do inciso II do parágrafo anterior, e conterá, sempre que necessário, advertência sobre os malefícios decorrentes de seu uso". (Grifos nossos)

6. Concordo, também, com a manifestação referente à constitucionalidade, oportunidade e conveniência de a alteração do conceito de bebidas alcoólicas ser efetivada por medida provisória, tendo em vista a presença dos requisitos de relevância e urgência.

7. É que, a despeito do tempo decorrido desde a publicação da Lei no 9.294, de 1996, a ser alterada, houve flagrante modificação do quadro de saúde pública, que se agravou ultimamente, motivado pelo aumento da ingestão de bebidas alcoólicas, consoante se depreende da análise da Exposição de Motivos do Decreto n⿳o 6.117, de 22 de maio de 2007, reproduzida às fls...., da NOTA em comento.

8. Assim, respondendo de forma objetiva à consulta, seria ilegal a resolução da Anvisa que restringisse a propaganda de bebidas alcoólicas com base a definição contida no Anexo I do Decreto nº 6.117, de 2007. O respaldo legal e constitucional para essa eventual resolução seria a alteração do parágrafo único do art. $1^{\text {o }}$ da Lei no 9.294, de 1996, proposta por projeto de lei ou medida provisória e submetida à apreciação do Congresso Nacional. À consideração. Brasília, 22 de junho de 2007 - Ronaldo Jorge Araujo Vieira Junior - Consultor-Geral da União. 
Ademais, também não se acolhe, no caso em análise, a possível tese de que a atuação da Anvisa esteja conforme a teoria da "deslegalização" de matérias do Poder Legislativo para o Poder Executivo. Com efeito, a Lei no 9.782, de 26 de janeiro de 1999, que criou a Anvisa, dispõe:

Art. 6‥ A Agência terá por finalidade institucional promover a proteção da saúde da população, por intermédio do controle sanitário da produção e da comercialização de produtos e serviços submetidos à vigilância sanitária, inclusive dos ambientes, dos processos, dos insumos e das tecnologias a eles relacionados, bem como o controle de portos, aeroportos e de fronteiras.

Art. 7º. Compete à Agência proceder à implementação e à execução do disposto nos incisos II a VII do art. $2^{2}$ desta Lei, devendo:

\section{[...]}

III - estabelecer normas, propor, acompanhar e executar as políticas, as diretrizes e as ações de vigilância sanitária;

IV - estabelecer normas e padrões sobre limites de contaminantes, resíduos tóxicos, desinfetantes, metais pesados e outros que envolvam risco à saúde;

$[\ldots]$

XV - proibir a fabricação, a importação, o armazenamento, a distribuição e a comercialização de produtos e insumos, em caso de violação da legislação pertinente ou de risco iminente à saúde;

XVI - cancelar a autorização de funcionamento e a autorização especial de funcionamento de empresas, em caso de violação da legislação pertinente ou de risco iminente à saúde;

Art. 8․․ Incumbe à Agência, respeitada a legislação em vigor, regulamentar, controlar e fiscalizar os produtos e serviços que envolvam risco à saúde pública.

$\S 1^{\circ}$ Consideram-se bens e produtos submetidos ao controle e fiscalização sanitária pela Agência:

$[\ldots]$

$\mathrm{X}$ - cigarros, cigarrilhas, charutos e qualquer outro produto fumígero, derivado ou não do tabaco;

Art. 15. Compete à Diretoria Colegiada:

$[\ldots]$

III - editar normas sobre matérias de competência da Agência; [...]. 
No Decreto n 3.029, de 16 de abril de 1999, que regulamenta a referida normativa, as competências da Anvisa estão assim dispostas:

Art. 3‥ Compete à Agência proceder à implementação e à execução do disposto nos incisos II a VII do art. 2º da Lei no 9.782, de 1999, devendo:

$[\ldots]$

XXIV - controlar, fiscalizar e acompanhar, sob o prisma da legislação sanitária, a propaganda e publicidade de produtos submetidos ao regime de vigilância sanitária.

Art. 4ํ․ Incumbe à Agência, respeitada a legislação em vigor, regulamentar, controlar e fiscalizar os produtos e serviços que envolvam risco à saúde pública.

$[\ldots]$

$\mathrm{X}$ - cigarros, cigarrilhas, charutos e qualquer outro produto fumígero, derivado ou não do tabaco;

Art. 11. Compete à Diretoria Colegiada a responsabilidade de analisar, discutir e decidir, em última instância administrativa, sobre matérias de competência da autarquia, bem como sobre:

IV - editar normas sobre matérias de competência da Agência; [...].

Numa leitura literal, aparentemente a Anvisa teria competência para editar normas nos moldes da RDC nํㅗㄴ 5 /2008, pois, poderia se argumentar que o próprio Poder Legislativo teria outorgado competência para dispor sobre as matérias ali dispostas. Teria havido verdadeira "deslegalização".

Contudo, não se trata, a nosso sentir, de hipótese abraçada pelo instituto da "deslegalização" em voga nas discussões doutrinárias acerca das transformações do direito público. Sob uma perspectiva sociojurídica sistêmica, não se desconhece o fato de que em vista da permeação de dados da realidade no direito, notadamente pelas novas relações sociais, econômicas, científicas e, especialmente, as tecnológicas, a filtragem dos novos ramos do conhecimento para a adequação da normatização tem se tornado cada vez mais problemática.

A transposição do direito racional para um texto aprovado pela vontade geral (de viés rousseauniano) impedia qualquer outra forma de se cogitar a existência de direito, diverso deste. Contudo, nos dias atuais essa premissa vem sofrendo mitigações. 
Segundo Parejo Alfonso (1993:31), o legislador, ao atribuir ao Poder Executivo tarefas públicas, está legitimado para conferir a esse poder um âmbito de responsabilidade própria, sobretudo na avaliação de questões técnicas, na ponderação de interesses contraditórios e na apreciação das evoluções futuras. García de Enterría (1998:106) comenta o instituto francês de "deslegalização" de matérias pelo Legislativo ao Executivo:

Desde la famosa Ley de 17 de agosto de 1948 se sortea de la técnica de la deslegalización o rebajamiento del rango normativo de la regulación de determinadas materias, que quedan así entregadas al poder reglamentario (matières relevant de la compétence du pouvoir règlementaire, dice expresamente esa Ley). Esta práctica, que se repetirá cada vez con mayor osadía, recordando ya casi exactamente la técnica de los anteriores Decretos-Leyes [...], va a ser sancionada por la autoridad del Consejo de Estado, consultado especialmente por el Gobierno sobre su compatibilidad con la Constitución.

Contudo, a "deslegalização" não envolve a atribuição de uma discricionariedade pelo Poder Legislativo ao Poder Executivo e suas entidades autônomas, pois não se trata de atuar sob o manto "intocável" da conveniência e oportunidade. Desse modo, quando a doutrina (pós)moderna cogita, em determinadas situações, a "deslegalização" para a compatibilização da escolha administrativa ao atual contexto jurídico-constitucional brasileiro, não se pode sustentar a retirada da base legal para a edição de normas e atuação das entidades administrativas como, no caso, a Anvisa.

O que se pode admitir é que entes descentralizados do Poder Público possam estruturar, operacionalizar (e não criar) aquilo que consta da moldura normativa.

Isto porque, "deslegalizar", no sentido enfocado por parte da doutrina contemporânea, significa não estarem indicados, na lei, os meios para atuação dos agentes estatais responsáveis pela regulação de sistemas sensíveis ao equilíbrio das ambivalências sociais. Contudo, no caso do controle, fiscalização e acompanhamento dos produtos de tabaco há normativa ordinária (lei) que disciplina regras de propaganda e, portanto, dita de forma vinculada a atividade da Anvisa.

Mesmo aquelas entidades regulatórias que, a nosso ver, normatizam, em tese, em vista do instituto da "deslegalização" (Anatel, Aneel etc.) não quer dizer que deva corresponder a um cheque em branco, associado ao instituto da discricionariedade administrativa, que se sustenta em bases axiológicas próprias do administrador público, o que vem enfrentando inúmeras críticas da doutrina contemporânea.

De acordo com a nova compreensão do direito administrativo no constitucionalismo atual há uma "tendência a reduzir margem" (García de Enterría, 2005:135), um "decréscimo" (Medauar, 2003:230) e mesmo "limitação" (Barroso, 2006:43-92) 
da discricionariedade na atuação do administrador público, uma verdadeira "restrição à dimensão constitucional e democrática" (Justen Filho, 2006:14) e "mayor objetividad en la apreciación de los elementos" (Madariaga Gutiérrez, 1993:47), importando "redefini-la, de acordo com os postulados do constitucionalismo pós-positivista, a partir da noção do princípio da juridicidade" (Moraes, 2002:37).

Nessa senda, a "deslegalização" - que não se comete à Anvisa no caso em exame - somente pode ocorrer pela exclusão legal de um comportamento a qualquer tipo de regra específica ou pela substituição do referencial normativo, indicando a nova fonte regradora, mas sempre com vistas à maior efetividade da norma legalitária.

\section{Agências reguladoras, legalidade e direitos fundamentais: limites aos poderes normativo e sancionatório da Anvisa na regulação de produtos fumigenos}

Com efeito, a normativa secundária (RDC no 54/2008) ultrapassa os limites estabelecidos na lei pelo Congresso Nacional. Portanto, esse desbordamento e abuso com a inovação de seus deveres e modificação de condições fixadas pelo legislador para o exercício dos direitos inerentes ao exercício da atividade econômica em comento significa deserção da juridicidade.

A Lei nº 9.294/96, disciplinando dispositivo constitucional (art. 220), só autoriza a exigência de imagens em embalagens de cigarros que sejam necessários para ilustrar o "sentido da mensagem" que visa desestimular ou, nos termos da lei, advertir quanto aos efeitos do fumo.

Diz, textualmente, a Lei no 9.294, de 15 de julho de 1996:

Art. 3‥ A propaganda comercial dos produtos referidos no artigo anterior só poderá ser efetuada através de pôsteres, painéis e cartazes, na parte interna dos locais de venda. (Redação dada pela Lei no 10.167 , de 27.12.2000)

$\S 2^{\mathrm{o}}$ A propaganda conterá, nos meios de comunicação e em função de suas características, advertência, sempre que possível falada e escrita, sobre os malefícios do fumo, bebidas alcoólicas, medicamentos, terapias e defensivos agrícolas, segundo frases estabelecidas pelo Ministério da Saúde, usadas sequencialmente, de forma simultânea ou rotativa. (Redação dada pela Medida Provisória no 2.190-34, de 2001)

§3 $3^{\circ}$ As embalagens e os maços de produtos fumígenos, com exceção dos destinados à exportação, e o material de propaganda referido no caput deste artigo conterão a advertência mencionada no $2^{\circ}{ }^{\circ}$ acompanhada de imagens 
ou figuras que ilustrem o sentido da mensagem. (Redação dada pela Medida Provisória no 2.190-34, de 2001)

Não pode a Anvisa ultrapassar esses limites legais.

Conclusivamente, seja diante da linha positivista ou mesmo sob o enfoque pós-positivista, a Anvisa não detém competência para editar normas que afetem escolhas públicas do Constituinte de 1988 nem, tampouco, do Poder Legislativo.

A regulação do que esteja contido em um dispositivo constitucional e legal, quando menos se tal ato trouxer consigo alguma ingerência na definição do âmbito do exercício da liberdade e da propriedade, só pode nos limites da lei.

\section{Conclusões}

Diante de todo o exposto, é justo apresentar as seguintes conclusões que, em conjunto, pretendem responder os quesitos apresentados pela consulente:

a) ressalvadas as hipóteses previstas na Constituição Federal de 1988, as escolhas políticas (conveniência e oportunidade) acerca da intensidade de intervenção estatal sobre as atividades econômicas devem observar - e se limitar - ao princípio da subsidiariedade e ao papel normativo e regulador do Estado;

b) o principal objetivo perseguido com a instituição de um modelo estatal regulatório é a cessão de capacidade decisória do poder central sobre aspectos técnicos para entidades descentralizadas. Em troca, busca-se trazer credibilidade e estabilidade, demonstrando-se, com isso, que a regulação estatal deve ser despolitizada, precisa ser razoável e proporcional, deve deixar de ser um assunto de governo para ser assunto de Estado;

c) a importância da função regulatória está em conformar a garantia de equilíbrio de um subsistema, por meio de mecanismos para sua efetividade com vistas ao ajuste das oscilações econômicas, mesmo contra suas próprias regras;

d) houve a escolha política (discricionária) de se disciplinar, na Constituição Federal e por meio de lei, as formas de autorização estatal para a produção, comercialização e publicidade de produtos derivados do tabaco, mesmo diante de potenciais riscos à saúde da população; e, paralelamente, cobrar dessa atividade econômica alta soma por meio de tributos;

e) duas formas de intervenção estatal incidem sobre a indústria do tabaco.

O disciplinamento legal da atividade, com inúmeras restrições para autori- 
zação e publicidade desta, diante dos riscos à saúde, e a regulação estatal descentralizada, por meio da Agência Nacional de Vigilância Sanitária (Anvisa), autarquia de regime especial;

f) a estruturação do controle e fiscalização da vigilância sanitária no Brasil decorreu de razões diversas de outros setores (ou subsistemas) que passaram a ser regulados por agências reguladoras, a exemplo dos subsistemas desestatizados de telecomunicações, distribuição de energia elétrica e transportes públicos;

g) a Anvisa não se enquadra na mesma intensidade, concepção e modelagem regulatória descentralizada, como ocorreu na estruturação dos setores que envolvem a regulação de serviços públicos desestatizados (Aneel, Anatel, ANTT, Antaq), nem, tampouco, na regulação de atividade monopolizada (ANP), na exploração de bens públicos (ANA), no fomento (Ancine) ou mesmo na regulação de atividade econômica em área sensível à sociedade e com risco microssistêmico (ANS);

h) a Anvisa se apresenta como uma regulação de atividade econômica não sistêmica (no caso da indústria do tabaco), voltada ao controle, fiscalização e acompanhamento nos moldes clássicos do poder de polícia estatal;

i) é constitucional, em tese, o exercício da função normativa secundária pelas entidades reguladoras, por não se detectar do ponto de vista jurídicoconstitucional qualquer usurpação da função legiferante, de competência do Poder Legislativo, nem, tampouco, do poder regulamentar de atribuição precípua do chefe do Poder Executivo;

j) toda a construção doutrinária "pós-moderna", para sustentar a constitucionalidade da normatização pelas agências reguladoras, se baseia na necessidade de equilíbrio sistêmico de setores regulados, impondo-se uma maleabilidade normativa inerente ao "novo" direito administrativo econômico;

k) no caso da Anvisa, em relação à indústria do tabaco, a concepção regulatória normativa é diversa, haja vista tratar-se de atuação fiscalizatória, normativa e sancionatória para o exercício, apenas, no âmbito do poder de polícia estatal descentralizado sobre determinadas atividades econômicas privadas (ainda que reforçado);

1) a regulação desenvolvida pela Anvisa sobre a indústria do tabaco não se enquadra na ideia de haver imperiosa regulação estatal descentralizada, usada como barreiras às pressões políticas e sociais, estruturada para promover o equilíbrio sistêmico de determinados setores; 
m) atende a juridicidade, em tese, o exercício do poder de polícia sanitária pela Anvisa desde que seja nos limites constitucionais e legais, com observância do devido processo legal, dos princípios da dignidade da pessoa humana, razoabilidade e proporcionalidade, sem abuso ou desvio de poder;

n) mesmo diante da mutação do direito público, a "crise" do princípio da legalidade e a teoria da "deslegalização" de matérias para o Executivo, e em se admitindo haver espaço, em regra, para que a Anvisa edite regras diante da incapacidade material do Parlamento prever todas as hipóteses a serem disciplinadas pelas normas primárias, de fato não poderia a Anvisa editar, no caso concreto objeto deste parecer, norma secundária (RDC no 54/2008) que contrarie a escolha pública definida pelo constituinte (art. 220) e pelo legislador ordinário (Lei no 9.782, de 26 de janeiro de 1999) em termos de propaganda dos produtos produzidos pela indústria do tabaco;

o) a RDC no 54/2008 ultrapassa os limites estabelecidos na lei pelo Congresso Nacional; aliás, como se manifestou a Advocacia-Geral da União no caso da propaganda de bebidas alcoólicas. Esse desbordamento e abuso com a inovação de seus deveres e modificação de condições fixadas pelo legislador para o exercício dos direitos inerentes ao exercício da atividade econômica em comento significa deserção da juridicidade;

p) a Lei no 9.294/96, disciplinando dispositivo constitucional (art. 220), só autoriza a exigência de imagens em embalagens de cigarros que ilustrem o "sentido da mensagem" que visa desestimular ou, nos termos da lei, advertir quanto aos efeitos do fumo;

q) as imagens impostas pela RDC Anvisa no 54, de 2008, são grotescas, inverídicas do ponto de vista médico e atingem, diretamente, o fundamento constitucional da dignidade da pessoa humana dos fumantes e, ainda, das crianças, dos não fumantes e, por que não dizer, dos comerciantes (ou, como diz a norma, dos titulares do "comércio varejista");

r) soluções extremadas como essa da Anvisa, de partir para o "tudo ou nada", com imagens falsas do ponto de vista médico, inaceitáveis pelo seu horror, grotescas, ofensivas, sem consultas, debates e audiências públicas, para, com isso, tentar combater, a qualquer custo, o tabagismo, e que, portanto, ignoram as consequências secundárias da preponderância de um único valor, desconsiderando, entre outros, o princípio da dignidade da pessoa humana, não são conformes ao direito, à justiça.

É o parecer, s.m.j.

\section{Sérgio Guerra}




\section{Referências}

ARAGÃO, Alexandre Santos de. Princípio da legalidade e poder regulamentar no estado contemporâneo. Revista de Direito Administrativo, Rio de Janeiro, v. 225, jul./set. 2001.

. Direito dos serviços públicos. Rio de Janeiro: Forense, 2007.

BANDEIRA DE MELLO, Celso Antônio. Curso de direito administrativo. 14. ed. São Paulo: Malheiros, 2002.

BARROSO, Luís Roberto. Interpretação e aplicação da Constituição. 6. ed. São Paulo: Saraiva, 2004.

- Neoconstitucionalismo e constitucionalização do direito: o triunfo tardio do direito constitucional no Brasil. Revista da Emerj, Rio de Janeiro, v. 9, n. 33, p. 43-92, 2006.

BÉCET, Jean-Marie; COLARD, Daniel. Les conditions d'Existence des Libertes. Paris: La Documentation Française, 1985.

BERMEJO VERA, José. El declive de la seguridad jurídica en el ordenamiento plural. Madrid: Civitas, 2005.

BIELSA, Rafael. Derecho administrativo. Buenos Aires: La Ley, 1939.

BINENBOJM, Gustavo. Agências reguladoras, legalidade e direitos fundamentais: limites aos poderes normativo e sancionatório da Anvisa na regulação de produtos fumígenos. Revista de Direito Público da Economia, v. 1, n. 1, p. 137-168, 2003.

- Uma teoria do direito administrativo: direitos fundamentais, democracia e constitucionalização. Rio de Janeiro: Renovar, 2006.

CABRAL DE MONCADA, Luis S. Lei e regulamento. Coimbra: Coimbra Editores, 2002.

CAETANO, Marcello. Princípios fundamentais do direito administrativo. Coimbra: Almedina, 1992.

CANARIS, Claus-Wilhelm. Pensamento sistemático e conceito de sistema na ciência do direito. Trad., introdução e notas António Menezes Cordeiro. Lisboa: Fundação Calouste Gulbenkian, 1996.

CASSESE, Sabino. La globalización jurídica. Trad. Luis Ortega, Isaac Martín Delgado e Isabel Gallego Córceles. Madrid: Marcial Pons, 2006.

CLÈVE, Clèmerson Merlin. Atividade legislativa do poder executivo. 2. ed. São Paulo: Revista dos Tribunais, 2000. 
CRETELLA JÚNIOR, José. Tratado de direito administrativo. Rio de Janeiro: Forense, 1968.

DWORKIN, Ronald. Taking Rights Seriously. Harvard: Harvard University Press, 1998.

GARCÍA DE ENTERRÍA, Eduardo. Legislación delegada, potestad reglamentaria y control judicial. 3. ed. Madrid: Civitas, 1998.

. Democracia, jueces y controle de la administración. 5. ed. Madrid: Civitas, 2005.

; FERNANDÉZ, Tomás-Ramón. Curso de derecho administrativo. 10. ed. Madrid: Civitas, 2001. t. I.

GOMES, Joaquim B. Barbosa. Agências reguladoras: a "metamorfose" do Estado e da democracia (uma reflexão de direito constitucional e comparado). Revista de Direito da Associação dos Procuradores do Novo Estado do Rio de Janeiro, v. IX. Direito da regulação. ARAGÃO, Alexandre Santos de (Org.). Rio de Janeiro: Lumen Juris, 2002.

GUERRA, Sérgio. Controle judicial dos atos regulatórios. Rio de Janeiro: Lumen Juris, 2005a.

. Normatização por entidades reguladoras independentes: uma contribuição para o desafio da tecnicidade. In: GUERRA, Sérgio (Coord.). Temas de direito regulatório. Rio de Janeiro: Freitas Bastos, $2005 \mathrm{~b}$.

. Discricionariedade e reflexividade: uma nova teoria sobre as escolhas administrativas. Belo Horizonte: Fórum, 2008.

JUSTEN FILHO, Marçal. O direito das agências reguladoras independentes. São Paulo: Dialética, 2002.

. Curso de direito administrativo. 2. ed. São Paulo: Saraiva, 2006.

LAUBADÈRE, André de. Direito público económico. Trad. Maria Teresa Costa. Coimbra: Almedina, 1985.

MADARIAGA GUTIÉRREZ, Mónica. Seguridad juridica y administración publica en el siglo XXI. 2. ed. Santiago: Editorial Jurídica de Chile, 1993.

MARQUES NETO, Floriano de Azevedo. Direito das telecomunicações e Anatel. In: SUNDFELD, Carlos Ari (Org.). Direito administrativo econômico. São Paulo: Malheiros, 2000.

- A nova regulação dos serviços públicos. Revista de Direito Administrativo, Rio de Janeiro, v. 228. p, 13-29, abr./jun. 2002. 
MEDAUAR, Odete. O direito administrativo em evolução. 2. ed. São Paulo: Revista dos Tribunais, 2003.

MEILÁN GIL, José Luis. Progreso tecnológico y servicios públicos. Madrid: Civitas, 2006.

MENDES, Conrado Hübner. Reforma do Estado e agências reguladoras. In: SUNDFELD, Carlos Ari (Coord.). Direito administrativo econômico. São Paulo: Malheiros, 2000 .

MORAES, Germana de Olivera. Controle jurisdicional da administração pública. São Paulo: Dialética, 2002.

MOREIRA NETO, Diogo de Figueiredo. Agência Nacional de Vigilância Sanitária: natureza jurídica, competência normativa, limites dos poderes regulatórios. Revista de Direito Administrativo, Rio de Janeiro, v. 215, p. 71-83, jan./mar. 1999.

Direito regulatório: a alternativa participativa e flexível para a administração pública de relações setoriais complexas no Estado democrático. Rio de Janeiro: Renovar, 2003.

. Mutações do direito público. Rio de Janeiro: Renovar, 2006.

MOREIRA, Vital. Auto-regulação profissional e administração pública. Coimbra: Almedina, 1997.

; MAÇAS, Fernanda. Autoridades reguladoras independentes. Coimbra: Coimbra Editores, 2003.

MÜLLER, Friedrich. Discour de la méthode juridique. Trad. Olivier Jouanjan. Paris: Presses Universitaires de France, 1996.

OTERO, Paulo. Legalidade e administração pública: o sentido da vinculação administrativa à juridicidade. Coimbra: Almedina, 2003.

PAREJO ALFONSO, Luciano. Administrar y juzgar: das funciones constitucionales distintas y complementarias. Madrid: Tecnos, 1993.

SOUTO, Marcos Juruena Villela. Desestatização, privatização, concessões, terceirizações e regulação. 4. ed. Rio de Janeiro: Lumen Juris, 2001.

SUNDFELD, Carlos Ari. Introdução às agências reguladoras. In: SUNDFELD, Carlos Ari (Coord.). Direito administrativo econômico. São Paulo: Malheiros, 2000.

SUNSTEIN, Cass R. Risk and reason: safety, law and the environment. Cambridge: Cambridge University, 2002. 